\title{
PENGARUH KEBERADAAN PERGURUAN TINGGI TERHADAP PERUBAHAN MORFOLOGI KAWASAN SEKITARNYA
}

\author{
A.Munggiarti ${ }^{a}$, I.Buchori ${ }^{\text {b }}$ \\ ${ }^{a}$ Pemerintah Kabupaten Banyumas, Indonesia, email: nailurrokhmah@gmail.com \\ ${ }^{b}$ Universitas Diponegoro, Indonesia, email: i.buchori@undip.ac.id
}

\begin{abstract}
Article Info;
Abstrak: This research aims to analyze the morphology changes of the area surrounding

Received: Jenderal Sudirman University (Unsoed), Purwokerto. It is important because according to the City Detail Spatial Plan (RDTR) of Purwokerto 2014-2034 Unsoed is planned as a center of

29 March 2015 educational services. It will increase the trade and service activities supporting the educational

in revised form: 15 April 2015 and residential activities. So, it would increase the intensity of activities that would indirectly affect the physical changes of the surrounding area. This research has used GIS-based spatial analysis to determine the land cover or landuse change, area of land conversion, change in

Accepted:

27 April 2015 building density, and descriptive analysis to identify the morphology and growth pattern of the area. In addition, the influence of the university on the morphological changes in the surrounding area is analyzed. The results can identify that Unsoed has been influencing

Available Online: significantly (more than 80\%) on the changes in the morphology of the area. It can be proven 30 April 2015 by the following findings: (1) The increasing built-up area surrounding the university, especially at a radius of $500 \mathrm{~m}$, which is $18.3 \%$ from the year 2003 to 2013. (2) The building density has

Keywords: Landuse Change, Unsoed, Growth Pattern, Urban Morphologi increased by $4.93 \%$ per year. (3) The growing activities tend to cluster around the neighborhood streets and along the primary collector street, which indicates the linear growth pattern, while in some parts, such as in Grendeng and Karangwangkal villages, the pattern is octopus form. (4) The proximity to Unsoed has become an important reason (81.2\%) for the establishment of buildings within the radius of 500 meters from the campus. (5) The influence of Unsoed is much greater in the villages of Grendeng and Karangwangkal where the campus is located than that in the villages outside the campus location, i.e. Bancarkembar, Sumampir and Pabuwaran Villages. (C) 2015 GJGP UNDIP. All rights reserved.
\end{abstract}

Info Artikel;

Diterima:

29 Maret 2015

Hasil Revisi :

15 April 2015

Disetujui:

27 April 2015

Publikasi On-Line: 30 April 2015

Kata kunci: Perubahan Guna lahan, Unsoed, Pola Pertumbuhan, Morfologi Kota

Abstract: Berdasarkan Rencana Detail Tata Ruang Kota (RDTR) Kawasan Perkotaan Purwokerto Tahun 2014-2034 menetapkan perguruan tinggi Universitas Jenderal Soedirman (Unsoed) sebagai pusat pelayanan pendidikan dan pengembangan kawasan orientasi pendidikan yang secara simultan menumbuhkan berbagai kegiatan perdagangan dan jasa pendukung aktivitas pendidikan yang ada serta permukiman, sehingga terjadi peningkatan intensitas kegiatan yang secara tidak langsung akan mempengaruhi perubahan fisik di kawasan sekitarnya. Hal ini memicu terjadinya perubahan penutupan/penggunaan lahan di sekitar kawasan, oleh karena itu penelitian ini bertujuan untuk mengkaji sejauh mana perubahan morfologi kawasan sekitar perguruan tinggi Unsoed Purwokerto akibat keberadaan perguruan tinggi Unsoed Purwokerto.Penelitian ini menggunakan pendekatan rasionalistik dengan metode penelitian deskriptif kuantitatif. Analisis yang digunakan pada penelitian ini adalah analisis citra untuk menentukan perubahan penutupan /penggunaan lahan, luas konversi lahan dan perubahan kepadatan bangunan, analisis figure/ground untuk melihat morfologi dan pola perkembangan kawasan serta analisis pembuktian pengaruh keberadaan perguruan tinggi Unsoed Purwokerto terhadap perubahan morfologi kawasan di sekitarnya dengan penyebaran kuesioner. Pada penelitian ini teknik sampling yang digunakan untuk menentukan jumlah sampel adalah teknik sampling probabilistik dengan clustered sampling berdasarkan area. Berdasarkan hasil penelitian diketahui bahwa keberadaan perguruan tinggi Unsoed Purwokerto telah mempengaruhi secara signifikan (lebih dari 80\%) terhadap terjadinya perubahan morfologi kawasan di sekitar perguruan tinggi Unsoed Purwokerto, hal ini dapat dibuktikan dengan adanya temuan studi sebagai berikut (1) Peningkatan luas lahan terbangun di kawasan perguruan tinggi Unsoed terutama pada radius $500 \mathrm{~m}$ dari kampus Unsoed Purwokerto sebesar 18,3\% dari tahun 2003 sampai 2013. (2) Kepadatan bangunan rata-rata per tahun meningkat 4,93\%. (3) Pola perkembangan kawasan yang cenderung mengelompok di sekitar jalan-jalan lingkungan, sepanjang jalan kolektor primer cenderung pola perkembangan linier dan perkembangan kawasan yang membentuk seperti gurita di lingkungan Kelurahan Grendeng dan 
Karangwangkal (4) Keberadaan perguruan tinggi Unsoed menjadi salah satu alasan pendirian bangunan pada radius 500 meter dari kampus sebesar 81,2\%. (5) Di Kelurahan Grendeng dan Karangwangkal dimana lokasi kampus Unsoed berada pengaruhnya lebih besar dibandingkan dengan kelurahan yang diluar lokasi kampus Unsoed yaitu Kelurahan Bancarkembar, Sumampir dan Pabuwaran. (C) 2015 GJGP UNDIP. All rights reserved.

\section{PENDAHULUAN}

Perkembangan kawasan perkotaan merupakan suatu proses perubahan keadaan kawasan perkotaan menjadi keadaan kawasan perkotaan yang baru dalam beberapa periode waktu yang berbeda. Berdasarkan Rencana Detail Tata Ruang Kota (RDTR) Kawasan Perkotaan Purwokerto Tahun 2014-2034 menetapkan perguruan tinggi Universitas Jenderal Soedirman (Unsoed) sebagai pusat pelayanan pendidikan serta merupakan pengembangan kawasan orientasi pendidikan yang secara simultan menumbuhkan berbagai kegiatan perdagangan dan kegiatan jasa pendukung aktivitas pendidikan yang ada serta permukiman, sehingga terjadi peningkatan intensitas kegiatan yang secara tidak langsung akan mempengaruhi perubahan fisik di kawasan sekitarnya. Hal ini akan menimbulkan terjadinya perubahan penutupan dan penggunaan lahan dan perubahan kepadatan bangunan di kawasan sekitar perguruan tinggi Unsoed Purwokerto.

Keberadaan perguruan tinggi Unsoed di kawasan perkotaan Purwokerto menjadi daya tarik bagi penduduk di luar kawasan kampus Unsoed untuk datang dan menetap di sekitar kawasan kampus Unsoed sehingga menimbulkan kebutuhan lahan serta kebutuhan sarana aktivitas pendidikan meningkat. Hal ini memicu terjadinya alih fungsi lahan dari lahan pertanian/lahan sawah menjadi non pertanian/lahan kering untuk memenuhi kebutuhan permukiman dan perumahan, kebutuhan kelengkapan sarana pendidikan dan fasilitas aktivitas mahasiswa dalam bidang pelayanan, perdagangan dan jasa. Berdasarkan permasalahan di atas, maka pertanyaan penelitian ini adalah sejauh mana perubahan morfologi yang terjadi di kawasan sekitar perguruan tinggi Unsoed Purwokerto akibat keberadaan perguruan tinggi tersebut.

\section{TUJUAN DAN SASARAN PENELITIAN}

Tujuan penelitian ini adalah untuk mengkaji sejauh mana perubahan morfologi kawasan sekitar perguruan tinggi Unsoed Purwokerto akibat keberadaan perguruan tinggi Unsoed Purwokerto dengan sasaran-sasaaran yang hendak dicapai adalah:

1. Menganalisis perubahan penutupan/penggunaan lahan dan luas konversi lahan di kawasan sekitar perguruan tinggi Unsoed Purwokerto.

2. Menganalasis perubahan kepadatan bangunan di kawasan sekitar perguruan tinggi Unsoed Purwokerto.

3. Menganalisis perubahan morfologi dan pola perkembangan kawasan di sekitar perguruan tinggi Unsoed Purwokerto

4. Menganalisis dan pembuktian bahwa keberadaan perguruan tinggi Unsoed Purwokerto mempengaruhi perubahan morfologi kawasan sekitar perguruan tinggi Unsoed Purwokerto.

\section{DATA DAN METODE}

Metode penelitian yang dilakukan adalah penelitian deskriptif kuantitatif dengan menggunakan analisis kuantitatif dan teknik pengambilan datanya dilakukan dengan menggunakan teknik sampling. Teknik sampling yang digunakan untuk menentukan jumlah sampel adalah teknik sampling probabilistik dengan clustered sampling berdasarkan area, sedangkan untuk menentukan calon anggota sampel dari sampel klaster area adalah dengan random sampling. 
Gambar 1. Kawasan Di Sekitar Perguruan Tinggi Unsoed Purwokerto (Sumber : Hasil Analisis, 2014)

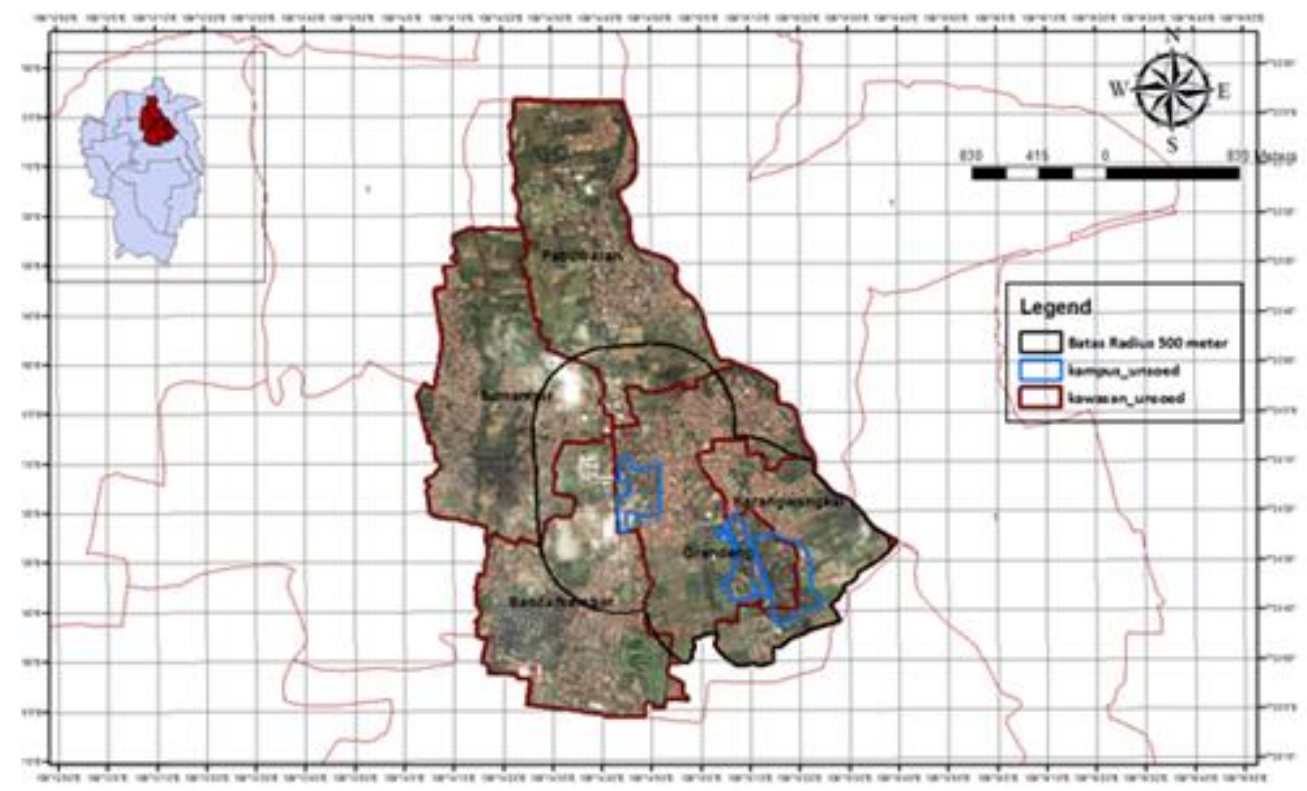

Obyek pada penelitian ini adalah kawasan sekitar perguruan tinggi Unsoed Purwokerto yang terdiri dari 5 kelurahan yaitu Kelurahan Bancarkembar, Sumampir, Pabuwaran, Grendeng dan Karangwangkal di Kecamatan Purwokerto Utara yang diambil dari data citra satelit Ikonos tahun 2003, Ikonos tahun 2008 dan Pleiades tahun 2013. Sedangkan untuk uji validitasi dilakukan observasi lapangan dan penyebaran kuesioner berdasarkan sampel area yang telah ditentukan dengan teknik sampling.

Tahapan Analisis yang dilakukan dalam penelitian ini adalah:

1. Analisis Citra

Analisis citra dilakukan dengan interpretasi citra satelit Ikonos Tahun 2003 dan 2008 serta Pleiades Tahun 2013 untuk menganalisis perubahan penutupan/penggunaan lahan, luas konversi lahan dan perubahan kepadatan bangunan di kawasan sekitar perguruan tinggi Unsoed Purwokerto dari Tahun 2003 sampai dengan Tahun 2013.

2. Analisis Figure/Ground.

Analisis Figure/ground digunakan untuk melihat pola perkembangan dan perubahan morfologi dari kawasan sekitar perguruan tinggi Unsoed Purwokerto.

3. Analisis pembuktian pengaruh

Berdasarkan hasil kuesioner dari responden di kawasan sekitar perguruan tinggi Unsoed Purwokerto pada radius 500 meter dari kampus, hasil analisis citra dan analisis Figure/Ground dapat digunakan untuk menganalisis pengaruh dan pembuktian pengaruh keberadaan perguruan tinggi Unsoed Purwokerto terhadap perubahan morfologi di kawasan sekitarnya dengan mendeskripsikan atau membuat gambaran secara sistematis, faktual dan akurat mengenai fakta-fakta serta fenomena yang terjadi di kawasan tersebut.

\subsection{Perkembangan Kota}

Pendekatan morfologi kota merupakan salah satu pendekatan yang berkaitan langsung dengan aspek penggunaan lahan kekotaan maupun kedesaan yang menyoroti eksistensi keruangan pada bentuk-bentuk wujud dari ciri-ciri atau karakteristiknya (Yunus, 1999:107). Menurut Nelson dalam Yunus (1999:114-120) menyatakan bahwa klasifikasi kota sesuai bentuk fisiknya dibagi kedalam 6 macam yaitu: bentuk bujur sangkar (the square cities), bentuk empat persegi panjang (the rectangular cities), bentuk kipas (fan shaped cities), bentuk bulat (rounded cities), bentuk pita (ribbon shaped cities), bentuk gurita atau bintang (octopus/star shaped cities), bentuk tidak berpola (unpatterned cities). 
Gambar 2. Bentuk-bentuk Kota (Hadi Sabari Yunus, 1999)

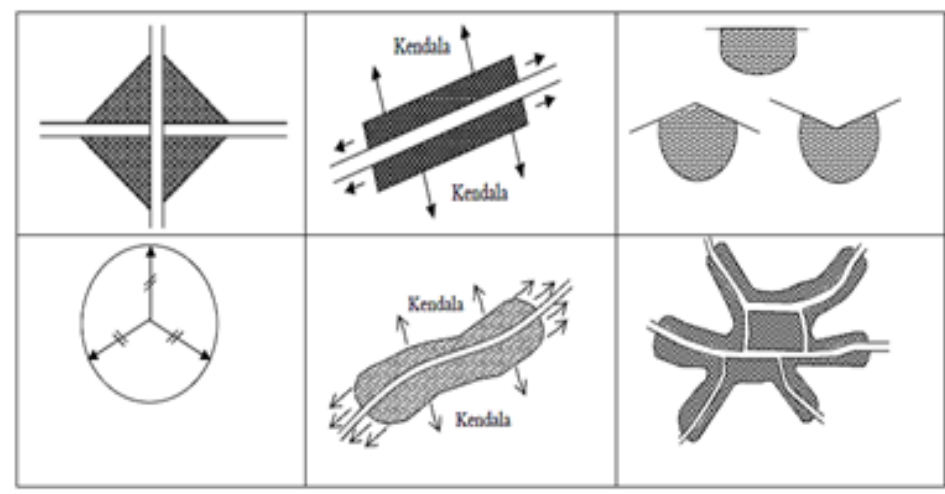

Teori figure ground dalam tata kota merupakan suatu hubungan tekstural antara bentuk yang dibangun (building mass) dan ruang terbuka (open space). Analisi ini dapat digunakan untuk mengidentifikasi tekstur dan pola-pola tata ruang perkotaan (urban fabric), serta mengidentifikasi masalah keteraturan massa/ruang perkotaan (Zahnd, 1999:79).

Berdasarkan terminologinya, figure merupakan istilah massa yang dibangun (biasanya di dalam gambar-gambar ditunjukkan dengan warna hitam) dan ground merupakan istilah untuk semua ruang yang berada di luar massa itu (biasanya ditunjukkan dengan warna putih). Pola-pola kawasan secara tekstural dapat diklasifikasi menjadi tiga kelompok, meliputi: pola kawasan yang bersifat homogen, pola kawasan yang bersifat heterogen dan pola kawasan yang menyebar (Zahnd, 1999:81).

Gambar 3. Pola-pola Kawasan (Markus Zahnd, 1999:81)

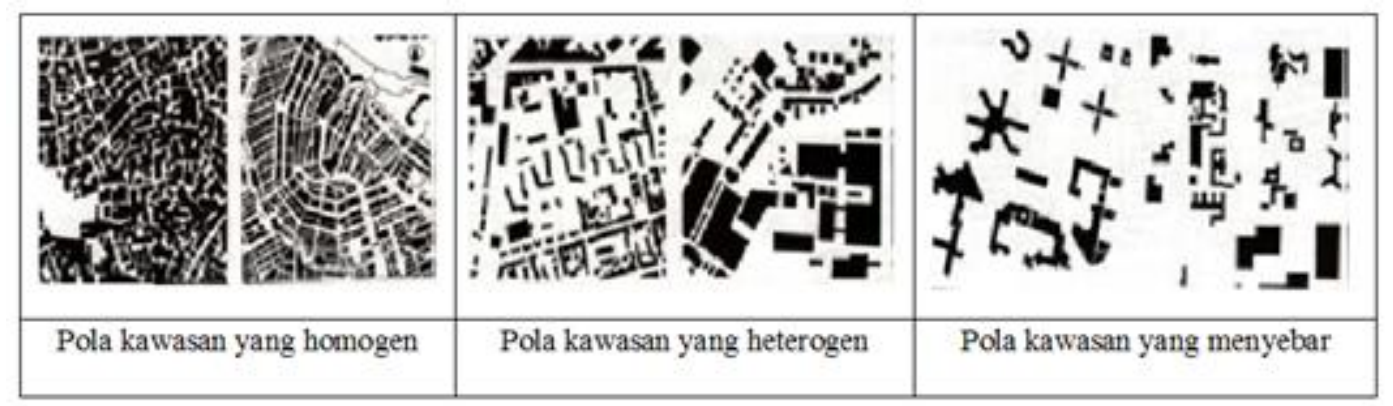

\subsection{Perubahan Kepadatan Bangunan}

Kepadatan bangunan dapat dihitung menggunakan luas bangunan per luas wilayah dengan rmenggunakan rumus :

$$
\text { Kepadatan Bangunan }=\frac{\Sigma \text { Seluruh Luas Atap }}{\Sigma \text { Luas blokbangunan }} \times 100 \%
$$

Tabel 1. Klasifikasi Kepadatan Bangunan (Ditjen Cipta Karya Dep. PU, 2006)

\begin{tabular}{cc}
\hline Klasifikasi & Kepadatan Bangunan \\
\hline Rendah & $<40 \%$ \\
Sedang & $40 \%-60 \%$ \\
Tinggi & $>60 \%$ \\
\hline
\end{tabular}

\subsection{Perubahan Penutupan/Penggunaan Lahan}

Menurut Sonis,et.al (2007) penggunaan lahan dapat dibagi kedalam 3 kategori besar yaitu vegetasi, pertanian dan lahan terbangun. Penggunaan lahan vegetasi terdiri dari hutan, semak belukar, padang rumput dan lahan kosong, penggunaan lahan pertanian terdiri dari lahan buah-buahan, tanaman budidaya dan lahan sawah, sedangkan lahan terbangun terdiri dari bangunan perkantoran, perdagangan, pelayanan, permukiman dan lain-lain.

Klasifikasi penutupan lahan menurut Selcuk Reis (2008) dibagi kedalam 7 kategori yaitu padang rumput, tanah gundul, air, perkotaan, pertanian, pohon jarum dan pohon yang berganti daun. Sedangkan menurut Yikalo H. Araya (2010) terdiri dari area terbangun, vegetasi, lahan non irigasi, 
lahan irigasi, hutan, lahan gundul dan badan air. Penggunaan lahan menurut Tine Ningal (2006) adalah pertanian, hutan, lahan rumput, perkebunan, perkotaan dan air. Sedangkan menurut Jian Peng (2008) adalah lahan hutan jarang, lahan hutan lebat, lahan rumput, lahan kering, sawah, badan air, lahan kosong, lahan bangunan dan lahan salju.

Penggunaan lahan menurut Xindong Du, et.al (2013) dan Si Yuan Wang (2010) dibagi ke dalam 6 kategori penggunaan yaitu Lahan Pertanian (cropland), hutan (woodland), padang rumput (grassland), badan air (water body), lahan terbangun (built-up land) dan lahan yang tidak digunakan (unused land). Sedangkan menurut Dan Hu, et. all (2008) dan Susana Martines (2012), kategori penggunaan lahan terbagi ke dalam kategori hutan (forest land); permukiman (settlement) yang terdiri dari bangunan, jalan beraspal, rel kereta api; lahan pertanian (cropland); lahan basah (wetland) terdiri dari air, padang rumput (grassland) terdiri dari rumput dan semak belukar, lahan lainnya (otherland) terdiri dari Es, batuan, salju dan tanah tandus.

Sistem klasifikasi penggunaan dan penutupan lahan dengan data penginderaan jauh (remote sensor data) menurut Anderson et al (1976) adalah lahan terbangun, lahan pertanian, peternakan, lahan hutan, air, lahan basah, lahan gundul, tundra dan salju.

Menurut Xindong du, et.al (2013), rata-rata perubahan penggunaan lahan selama periode waktu yang diteliti dapat diperoleh dengan menggunakan rumus:

$$
C=\frac{L U t 2-L U t 1}{t}
$$

Dimana $\mathrm{C}$ adalah rata-rata perubahan lahan sesuai kategori penggunaan lahan yang dipakai, Lut1 dan Lut2 adalah luas lahan pada waktu $\mathrm{t} 1$ dan $\mathrm{t} 2$, $\mathrm{t}$ adalah interval periode tahun yang dihitung.

\subsection{Interpretasi Citra}

Interpretasi citra merupakan suatu cara untuk mengenali dan menilai suatu objek,fenomena dan gejala yang ada di permukaan bumi dengan data citra satelit maupun foto udara. Unsur interpretasi citra terdiri dari sembilan kunci yaitu rona atau warna, tekstur, ukuran, bentuk, pola, tinggi, bayangan, situs dan asosiasi. Sembilan unsur interpretasi citra dapat digambarkan secara hirarki berdasarkan tingkat kerumitannnya pada gambar di bawah ini:

Gambar 4. Unsur Interpretasi Citra Secara Manual/Visual (Sumber : Sutanto, 1999)

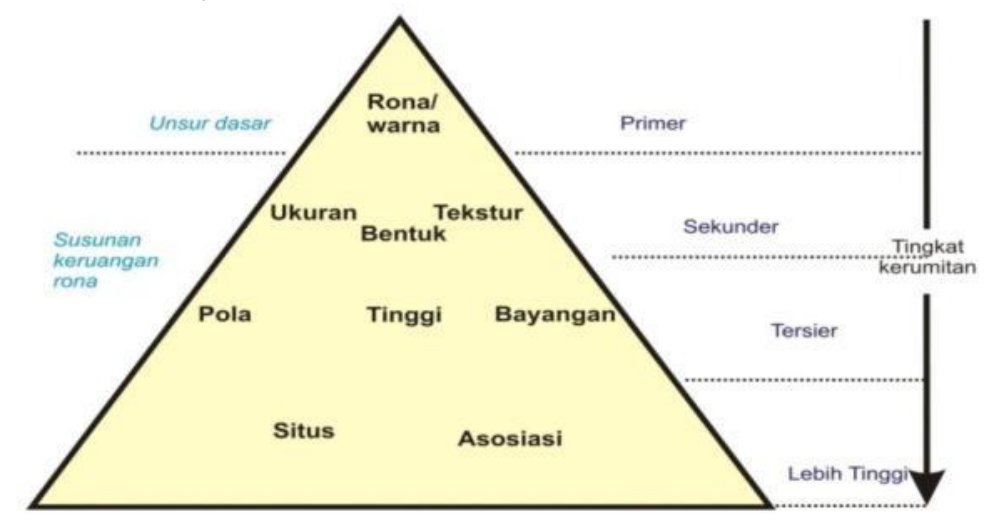

\section{HASIL DAN PEMBAHASAN}

4.1 Analisis Perubahan Penutupan / Penggunaan Lahan

Berdasarkan klasifikasi penutupan/penggunaan lahan dari beberapa sumber yang telah diuraikan, klasifikasi penggunaan lahan pada penelitian ini dibagi kedalam 4 kategori penggunaan lahan yang disesuaikan dengan kondisi di kawasan sekitar perguruan tinggi Unsoed Purwokerto yaitu lahan pertanian, badan air, lahan terbangun dan lahan kosong. Kategori lahan pertanian terdiri dari penggunaan lahan untuk sawah, kebun/pekarangan, RTH dan tegalan, badan air terdiri dari sungai dan perikanan, lahan terbangun terdiri dari bangunan, jalan, makam dan sarana olahraga, sedangkan lahan kosong adalah lahan yang tidak atau belum dimanfaatkan.

Berdasarkan hasil analisis pengolahan citra satelit Ikonos Tahun 2003, Ikonos Tahun 2008 dan Pleiades Tahun 2013 dapat diperoleh perubahan penutupan/penggunaan lahan di kawasan sekitar 
perguruan tinggi Unsoed Purwokerto yang terjadi dari tahun 2003 sampai dengan tahun 2013. Penurunan luas lahan pertanian terbesar pada kisaran tahun 2003 sampai tahun 2008 di seluruh wilayah pada kawasan di sekitar perguruan tinggi Unsoed Purwokerto terjadi di Kelurahan Bancarkembar yang sebagian besar berubah menjadi lahan kosong. Sedangkan pada radius 500 meter dari perguruan tinggi Unsoed Purwokerto terjadi di Kelurahan Pabuwaran yang sebagian besar juga berubah menjadi lahan kosong, hal ini disebabkan karena di Kelurahan Pabuwaran pada radius 500 meter banyak digunakan untuk pengembangan lahan terbangun yang difungsikan untuk usaha.

Peningkatan luas lahan terbangun terbesar di seluruh wilayah di kawasan sekitar perguruan tinggi Unsoed maupun pada radius 500 meter dari perguruan tinggi Unsoed Purwokerto terjadi di Kelurahan Sumampir, hal ini disebabkan salah satunya adalah munculnya beberapa perumahan di Kelurahan Sumampir. Peningkatan penggunaan lahan terbesar yang terjadi di kawasan sekitar perguruan tinggi Unsoed Purwokerto pada radius 500 meter dari kampus adalah peningkatan luas lahan kosong, hal ini banyak disebabkan oleh kecenderungan rencana pengembangan lahan terbangun pada area tersebut sehingga lahan pertanian banyak yang dikosongkan.

Gambar 5. Peta Penggunaan Lahan Di Kawasan Sekitar Perguruan Tinggi Unsoed Purwokerto Tahun 2003 dan 2008 (Hasil Analisis, 2015)

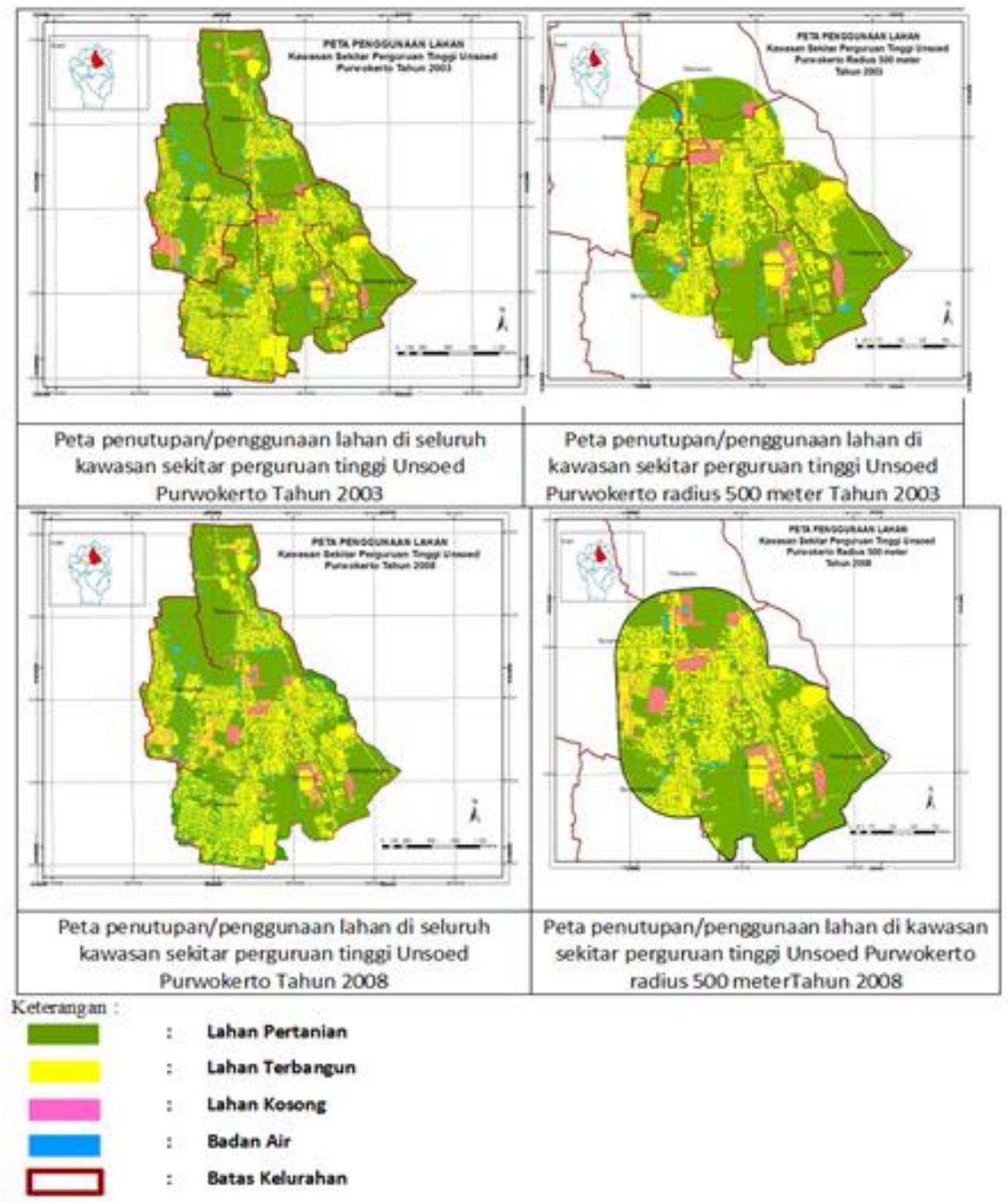


Tabel 2. Perubahan Penutupan/Penggunaan Lahan Di Kawasan Sekitar Perguruan Tinggi Unsoed

Purwokerto Dari Tahun 2003 Sampai Dengan Tahun 2008 (dalam m2) (Hasil Analisis, 2015)

\begin{tabular}{llcccccc}
\hline No. & \multicolumn{1}{c}{$\begin{array}{c}\text { Penggunaan } \\
\text { Lahan }\end{array}$} & Tahun 2003 & Tahun 2008 & $\begin{array}{c}\text { Perubahan } \\
\text { lahan dalam } \\
\mathbf{5} \text { Tahun }\end{array}$ & $\begin{array}{c}\text { Prosentase } \\
\text { dari Luas } \\
\text { Wilayah }\end{array}$ & $\begin{array}{c}\text { Perubahan } \\
\text { rata2 per } \\
\text { tahun }\end{array}$ & $\begin{array}{c}\text { Prosentase } \\
\text { dari Luas } \\
\text { Wilayah }\end{array}$ \\
\hline $\mathbf{1}$ & Lahan Pertanian & $4.114 .021,53$ & $3.889 .805,73$ & $(224.215,80)$ & $-3,5 \%$ & $(44.843,16)$ & $-0,71 \%$ \\
\hline $\mathbf{2}$ & Lahan Terbangun & $1.747 .817,51$ & $1.937 .209,95$ & $189.392,44$ & $3,0 \%$ & $37.878,49$ & $0,60 \%$ \\
\hline $\mathbf{3}$ & Badan Air & $195.344,83$ & $185.032,45$ & $(10.312,38)$ & $-0,2 \%$ & $(2.062,48)$ & $-0,03 \%$ \\
\hline $\mathbf{4}$ & Lahan Kosong & $275.064,21$ & $320.199,94$ & $45.135,73$ & $0,7 \%$ & $9.027,15$ & $0,14 \%$ \\
& Jumlah & $6.332 .248,08$ & $6.332 .248,08$ & & & & \\
\hline
\end{tabular}

Tabel 3. Perubahan Penutupan/Penggunaan Lahan Di Kawasan Sekitar Perguruan Tinggi Unsoed Purwokerto Radius 500 Meter dari Tahun 2003 Sampai Tahun 2008 (dalam m2) (Hasil Analisis, 2015)

\begin{tabular}{llcccccc}
\hline No. & $\begin{array}{c}\text { Penggunaan } \\
\text { Lahan }\end{array}$ & Tahun 2003 & Tahun 2008 & $\begin{array}{c}\text { Perubahan } \\
\text { lahan dalam } \\
\text { 5 Tahun }\end{array}$ & $\begin{array}{c}\text { Prosentase } \\
\text { dari Luas } \\
\text { Wilayah }\end{array}$ & $\begin{array}{c}\text { Perubahan } \\
\text { rata2 per } \\
\text { tahun }\end{array}$ & $\begin{array}{c}\text { Prosentase } \\
\text { dari Luas } \\
\text { Wilayah }\end{array}$ \\
\hline $\mathbf{1}$ & Lahan Pertanian & $1.816 .415,97$ & $1.671 .161,70$ & $(145.254,27)$ & $-5,1 \%$ & $(29.050,85)$ & $-1,01 \%$ \\
\hline $\mathbf{2}$ & Lahan Terbangun & $821.932,56$ & $903.796,33$ & $81.863,77$ & $2,9 \%$ & $16.372,75$ & $0,57 \%$ \\
\hline $\mathbf{3}$ & Badan Air & $76.787,22$ & $71.784,65$ & $(5.002,57)$ & $-0,2 \%$ & $(1.000,51)$ & $-0,03 \%$ \\
\hline $\mathbf{4}$ & Lahan Kosong & $150.244,91$ & $218.637,98$ & $68.393,07$ & $2,4 \%$ & $13.678,61$ & $0,48 \%$ \\
& Jumlah & $2.865 .380,66$ & $2.865 .380,66$ & & & & \\
\hline
\end{tabular}

Perubahan penggunaan lahan yang terjadi di sekitar perguruan tinggi Unsoed Purwokerto dari tahun 2008 sampai dengan tahun 2013 radius 500 meter dari kampus Unsoed, terjadi penambahan luas lahan pertanian yang diperoleh dari lahan kosong yang kembali difungsikan menjadi lahan pertanian apakah itu untuk persawahan, perkebunan maupun ruang terbuka hijau (RTH).

Tabel 4. Perubahan Penutupan/Penggunaan Lahan Di Kawasan Sekitar Perguruan Tinggi Unsoed Purwokerto dari Tahun 2008 Sampai Dengan Tahun 2013 ( dalam m2) (Hasil Analisis, 2015)

\begin{tabular}{llcccccc}
\hline No. & $\begin{array}{c}\text { Penggunaan } \\
\text { Lahan }\end{array}$ & Tahun 2008 & Tahun 2013 & $\begin{array}{c}\text { Perubahan } \\
\text { lahan dalam } \\
\text { 5 Tahun }\end{array}$ & $\begin{array}{c}\text { Prosentase } \\
\text { dari Luas } \\
\text { Wilayah }\end{array}$ & $\begin{array}{c}\text { Perubahan } \\
\text { rata2 per } \\
\text { tahun }\end{array}$ & $\begin{array}{c}\text { Prosentase } \\
\text { dari Luas } \\
\text { Wilayah }\end{array}$ \\
\hline $\mathbf{1}$ & Lahan Pertanian & $3.889 .805,73$ & $3.887 .525,30$ & $(2.280,437)$ & $-0,04 \%$ & $(456,087)$ & $-0,01 \%$ \\
$\mathbf{2}$ & Lahan Terbangun & $1.937 .209,95$ & $2.048 .351,64$ & $111.141,684$ & $1,76 \%$ & $22.228,337$ & $0,35 \%$ \\
$\mathbf{3}$ & Badan Air & $185.032,45$ & $171.372,11$ & $(13.660,340)$ & $-0,22 \%$ & $(2.732,068)$ & $-0,04 \%$ \\
\hline $\mathbf{4}$ & Lahan Kosong & $320.199,94$ & $224.999,04$ & $(95.200,906)$ & $-1,50 \%$ & $(19.040,181)$ & $-0,30 \%$ \\
\hline & Jumlah & $6.332 .248,08$ & $6.332 .248,08$ & & & & \\
\hline
\end{tabular}

Tabel 5. Perubahan Penutupan/Penggunaan Lahan Di Kawasan Sekitar Perguruan Tinggi Unsoed Purwokerto Radius 500 meter dari Tahun 2008 sampai Tahun 2013 (dalam m2) (Hasil Analisis, 2015)

\begin{tabular}{cccccccc}
\hline No. & $\begin{array}{c}\text { Penggunaan } \\
\text { Lahan }\end{array}$ & Tahun 2008 & Tahun 2013 & $\begin{array}{c}\text { Perubahan } \\
\text { lahan dalam } \\
\text { 5 Tahun }\end{array}$ & $\begin{array}{c}\text { Prosentase } \\
\text { dari Luas } \\
\text { Wilayah }\end{array}$ & $\begin{array}{c}\text { Perubahan } \\
\text { rata2 per } \\
\text { tahun }\end{array}$ & $\begin{array}{c}\text { Prosentase } \\
\text { dari Luas } \\
\text { Wilayah }\end{array}$ \\
\hline $\mathbf{1}$ & Lahan Pertanian & $1.671 .161,70$ & $1.682 .067,29$ & $10.905,589$ & $0,4 \%$ & $2.181,118$ & $0,03 \%$ \\
\hline $\mathbf{2}$ & Lahan Terbangun & $903.796,33$ & $972.270,86$ & $68.474,532$ & $1,1 \%$ & $13.694,906$ & $0,22 \%$ \\
\hline $\mathbf{3}$ & Badan Air & $\mathbf{7 1 . 7 8 4 , 6 5}$ & $65.831,11$ & $(5.953,534)$ & $-0,1 \%$ & $(1.190,707)$ & $-0,02 \%$ \\
\hline $\mathbf{4}$ & Lahan Kosong & $218.637,98$ & $145.211,39$ & $(73.426,588)$ & $-1,2 \%$ & $(14.685,318)$ & $-0,23 \%$ \\
\hline & Jumlah & $2.865 .380,66$ & $2.865 .380,66$ & & & & \\
\hline
\end{tabular}

Prosentase peningkatan luas lahan pertanian terbesar pada kisaran tahun 2008 sampai tahun 2013 di seluruh wilayah pada kawasan di sekitar perguruan tinggi Unsoed Purwokerto terjadi di Kelurahan Grendeng yang dikuti oleh Kelurahan Pabuwaran yang sebagian besar disebabkan karena 
pemanfaatan kembali lahan kosong menjadi sawah, kebun maupun ruang terbuka hijau. Di Kelurahan Grendeng banyak terjadi alih fungsi lahan dari lahan kosong menjadi ruang terbuka hijau pada sekitar kawasan yang didirikan bangunan kampus. Sedangkan prosentase peningkatan luas lahan pertanian terbesar pada kisaran tahun 2008 sampai tahun 2013 pada kawasan di sekitar perguruan tinggi Unsoed Purwokerto pada radius 500 meter dari kampus terjadi di Kelurahan Pabuwaran.

Prosentase perubahan penggunaan lahan terbangun di kawasan sekitar kampus perguruan tinggi Unsoed Purwokerto secara menyeluruh lebih besar penambahannya dari pada perubahan penggunaan lahan pertanian di kawasan sekitar perguruan tinggi Unsoed Purwokerto radius 500 meter dari perguruan tinggi Unsoed Purwokerto. Hal ini membuktikan bahwa pada periode waktu dari tahun 2008 sampai tahun 2013 terjadi penambahan bangunan di sekitar kawasan perguruan tinggi Unsoed Purwokerto radius 500 meter dari kampus Unsoed lebih sedikit dari pada di luar radius 500 meter dari perguruan tinggi Unsoed Purwokerto.

Prosentase peningkatan luas lahan terbangun terbesar di seluruh wilayah di kawasan sekitar perguruan tinggi Unsoed maupun pada radius 500 meter dari kampus Unsoed Purwokerto terjadi di Kelurahan Karangwangkal, hal ini disebabkan salah satunya adalah munculnya perumahan di Kelurahan Karangwangkal.

Gambar 6. Peta Penggunaan Lahan Di Kawasan Sekitar Perguruan Tinggi Unsoed Purwokerto Tahun 2013 (Hasil Analisis, 2015)

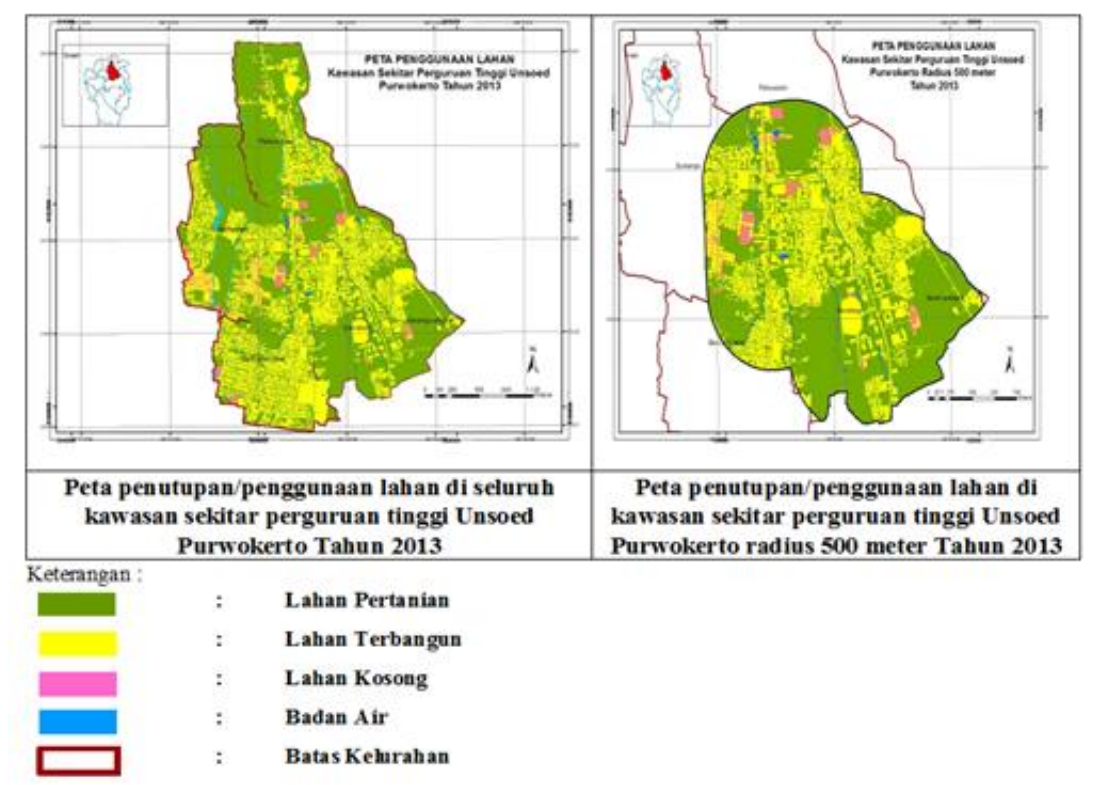

Prosentase peningkatan luas lahan pertanian terbesar pada kisaran tahun 2008 sampai tahun 2013 di seluruh wilayah pada kawasan di sekitar perguruan tinggi Unsoed Purwokerto terjadi di Kelurahan Grendeng yang dikuti oleh Kelurahan Pabuwaran yang sebagian besar disebabkan karena pemanfaatan kembali lahan kosong menjadi sawah, kebun maupun ruang terbuka hijau. Di Kelurahan Grendeng banyak terjadi alih fungsi lahan dari lahan kosong menjadi ruang terbuka hijau pada sekitar kawasan yang didirikan bangunan kampus. Sedangkan prosentase peningkatan luas lahan pertanian terbesar pada kisaran tahun 2008 sampai tahun 2013 pada kawasan di sekitar perguruan tinggi Unsoed Purwokerto pada radius 500 meter dari kampus terjadi di Kelurahan Pabuwaran.

Prosentase peningkatan luas lahan terbangun terbesar di seluruh wilayah di kawasan sekitar perguruan tinggi Unsoed maupun pada radius 500 meter dari kampus Unsoed Purwokerto terjadi di Kelurahan Karangwangkal, hal ini disebabkan salah satunya adalah munculnya perumahan di Kelurahan Karangwangkal.

\subsection{Analisis Luas Konversi Lahan}

Analisis luas konversi lahan dilakukan untuk mengetahui luas lahan yang berubah penggunaannya dari tahun sebelumnya, Hal ini dapat dilihat dari tabel matriks konversi penggunaan lahan dari tahun 2003 sampai tahun 2013 pada kawasan di sekitar perguruan tinggi Unsoed 
Purwokerto yang terinspirasi dari format tabel matriks konversi penggunaan lahan dari Dan Hu et.al (2008) dan Xindong Du et.al (2013). Luas konversi penggunaan lahan pertanian yang terjadi di kawasan perguruan tinggi Unsoed Purwokerto secara menyeluruh selama periode waktu 5 tahun dari tahun 2003 sampai tahun 2008 paling besar berubah penggunaannya menjadi lahan terbangun sebesar $3,43 \%$ diikuti oleh perubahan penggunaan ke lahan kosong 2,73\% dan perubahan menjadi badan air $0.13 \%$ dari luas pertanian pada tahun 2003.

Tabel 6. Matrik Konversi Penggunaan Lahan dari Tahun 2003 sampai Tahun 2008 Di Kawasan Perguruan Tinggi Unsoed Purwokerto (Unit : m2) (Hasil Analisis, 2015)

\begin{tabular}{|c|c|c|c|c|c|}
\hline \multirow[b]{2}{*}{ Tahun 2003} & \multicolumn{5}{|c|}{ Tahun 2008} \\
\hline & $\begin{array}{c}\text { Lahan } \\
\text { Pertanian }\end{array}$ & $\begin{array}{c}\text { Lahan } \\
\text { Terbangun }\end{array}$ & Badan Air & $\begin{array}{l}\text { Lahan } \\
\text { Kosong }\end{array}$ & Total Area \\
\hline Lahan Pertanian & $3.855 .126,250$ & $141.037,707$ & $5.421,666$ & $112.435,907$ & $4.114 .021,530$ \\
\hline Lahan Terbangun & 855,595 & $1.746 .961,916$ & 0 & 0 & $1.747 .817,511$ \\
\hline Badan Air & $12.884,728$ & $3.513,215$ & $178.946,887$ & 0 & $195.344,829$ \\
\hline Lahan Kosong & $20.939,161$ & $45.697,115$ & 663,90 & $207.764,036$ & $275.064,210$ \\
\hline Total Area & $3.889 .805,733$ & $1.937 .209,953$ & $185.032,452$ & $320.199,942$ & $6.332 .248,081$ \\
\hline
\end{tabular}

Sedangkan luas konversi penggunaan lahan pertanian yang terjadi di kawasan perguruan tinggi Unsoed Purwokerto radius 500 meter yang paling besar perubahannya adalah menjadi lahan kosong sebesar 5,3\%, diikuti oleh perubahan penggunaan menjadi lahan terbangun sebesar 3,9 \% dan badan air sebesar 0,10\% dari luas lahan pertanian pada tahun 2003. Hal ini menunjukkan bahwa prosentase terjadinya konversi lahan pertanian menjadi lahan terbangun dan lahan kosong pada radius 500 meter lebih besar dibandingkan di luar area radius 500 meter.

Tabel 7. Matrik Konversi Penggunaan Lahan Dari Tahun 2003 Sampai 2008 Di Kawasan Perguruan Tinggi Unsoed Purwokerto Radius 500 Meter (Unit : M2) (Hasil Analisis, 2015)

\begin{tabular}{cccccc}
\hline \multirow{2}{*}{ Tahun 2003 } & \multicolumn{5}{c}{ Tahun 2008 } \\
\cline { 2 - 6 } Lahan Pertanian & Lahan Pertanian & Lahan Terbangun & Badan Air & Lahan Kosong & Total Area \\
\hline Lahan Terbangun & $1.647923,336$ & $71.233,995$ & $1.735,945$ & $95.522,699$ & $\mathbf{1 . 8 1 6 . 4 1 5 , 9 7 5}$ \\
\hline Badan Air & 560,133 & $821.372,425$ & 0 & 0 & $\mathbf{8 2 1 . 9 3 2 , 5 5 8}$ \\
\hline Lahan Kosong & $5.957,290$ & $1.445,123$ & $69.384,804$ & 0 & $\mathbf{7 6 . 7 8 7 , 2 1 6}$ \\
\hline Total Area & $16.720,943$ & $9.744,787$ & 663,90 & $123.115,282$ & $\mathbf{1 5 0 . 2 4 4 , 9 1 1}$ \\
\hline
\end{tabular}

Pada tahun 2003 sampai tahun 2008 di kawasan sekitar perguruan tinggi Unsoed Purwokerto secara menyeluruh maupun dalam radius 500 meter dari kampus Unsoed terjadi perubahan lahan terbangun menjadi lahan pertanian, prosentasi luas konversi dari luas lahan terbangun pada radius 500 meter lebih besar dibandingkan dengan luas konversi secara menyeluruh, ini menunjukkan bahwa perubahan lahan terbangun menjadi lahan pertanian lebih besar di dalam area radius 500 meter.

Tabel 8. Matrik Konversi Penggunaan Lahan dari Tahun 2008 sampai Tahun 2013 Di Kawasan Perguruan Tinggi Unsoed Purwokerto (Unit : m2) (Hasil Analisis, 2015)

\begin{tabular}{cccccc}
\hline \multirow{2}{*}{ Tahun 2008 } & \multicolumn{5}{c}{ Tahun 2013 } \\
\cline { 2 - 6 } & $\begin{array}{c}\text { Lahan } \\
\text { Pertanian }\end{array}$ & Lahan Terbangun & Badan Air & Lahan Kosong & Total Area \\
Lahan Pertanian & $3.749 .800,979$ & $83.192,459$ & $24.178,450$ & $17.628,512$ & $\mathbf{3 . 8 8 9 . 8 0 5 , 7 3 3}$ \\
\hline Lahan Terbangun & 682,2531 & $1.936 .478,342$ & 95,131 & 0 & $\mathbf{1 . 9 3 7 . 2 0 9 , 9 5 3}$ \\
\hline Badan Air & $35.336,772$ & $3.183,071$ & $146.466,836$ & 0 & $\mathbf{1 8 5 . 0 3 2 , 4 5 2}$ \\
\hline Lahan Kosong & $101.705,292$ & $25.497,765$ & 631,69 & $207.370,524$ & $\mathbf{3 2 0 . 1 9 9 , 9 4 2}$ \\
\hline Total Area & $\mathbf{3 . 8 8 7 . 5 2 5 , 2 9 6}$ & $\mathbf{2 . 0 4 8 . 3 5 1 , 6 3 7}$ & $\mathbf{1 7 1 . 3 7 2 , 1 1 2}$ & $\mathbf{2 2 4 . 9 9 9 , 0 3 6}$ & $\mathbf{6 . 3 3 2 . 2 4 8 , 0 8 1}$ \\
\hline
\end{tabular}


Tabel 9. Matrik Konversi Penggunaan Lahan Dari Tahun 2008 Sampai 2013 Di Kawasan

Perguruan Tinggi Unsoed Purwokerto Radius 500 Meter (Unit : m2) (Hasil Analisis, 2015)

\begin{tabular}{cccccc}
\hline \multirow{2}{*}{ Tahun 2008 } & \multicolumn{5}{c}{ Tahun 2013 } \\
\cline { 2 - 6 } & $\begin{array}{c}\text { Lahan } \\
\text { Pertanian }\end{array}$ & Lahan Terbangun & Badan Air & Lahan Kosong & Total Area \\
Lahan Pertanian & $1.587 .883,926$ & $44.596,085$ & $2.268,603$ & $6.288,349$ & $\mathbf{1 . 6 7 1 . 1 6 1 , 7 0 1}$ \\
Lahan Terbangun & 486,6123 & $903.309,718$ & 0,000 & 0,000 & $\mathbf{9 0 3 . 7 9 6 , 3 3 0}$ \\
\hline Badan Air & $8.144,241$ & 623,834 & $63.016,573$ & 0,000 & $\mathbf{7 1 . 7 8 4 , 6 4 8}$ \\
\hline Lahan Kosong & $85.552,511$ & $23.741,225$ & 545,94 & $138.923,045$ & $\mathbf{2 1 8 . 6 3 7 , 9 8 1}$ \\
\hline Total Area & $\mathbf{1 . 6 8 2 . 0 6 7 , 2 9 0}$ & $\mathbf{9 7 2 . 2 7 0 , 8 6 3}$ & $\mathbf{6 5 . 8 3 1 , 1 1 4}$ & $\mathbf{1 4 5 . 2 1 1 , 3 9 3}$ & $\mathbf{2 . 8 6 5 . 3 8 0 , 6 6 0}$ \\
\hline
\end{tabular}

Luas konversi penggunaan lahan pertanian yang terjadi di kawasan perguruan tinggi Unsoed Purwokerto secara menyeluruh maupun dalam radius 500 meter dari kampus Unsoed selama periode waktu dari tahun 2008 sampai tahun 2013 paling besar berubah penggunaannya adalah menjadi lahan terbangun diikuti oleh perubahan penggunaan ke badan air. Pada periode tahun 2008 sampai tahun 2013 di kawasan sekitar perguruan tinggi Unsoed Purwokerto terjadi perubahan penggunaan lahan terbangun menjadi lahan pertanian dan badan air, luas konversi penggunaan lahan terbangun menjadi lahan pertanian terjadi di kawasan sekitar perguruan tinggi Unsoed Purwokerto di luar radius 500 meter dari kampus Unsoed Purwokerto maupun dalam radius 500 meter sedangkan luas konversi penggunaan lahan terbangun menjadi badan air terjadi di kawasan sekitar perguruan tinggi Unsoed Purwokerto diluar radius 500 meter dari kampus Unsoed Purwokerto.

Pada tahun 2008 sampai tahun 2013 di kawasan sekitar perguruan tinggi Unsoed Purwokerto secara menyeluruh maupun dalam radius 500 meter dari kampus Unsoed terjadi perubahan lahan kosong menjadi lahan pertanian, dengan prosentasi luas konversi dari luas lahan kosong pada radius 500 meter sebesar $34,39 \%$ dari luas lahan kosong pada radius 500 meter lebih besar dibandingkan dengan luas konversi secara menyeluruh yaitu sebesar 30,34\% dari luas lahan kosong di seluruh wilayah, hal ini menunjukkan bahwa perubahan lahan kosong menjadi lahan pertanian di dalam area radius $\mathbf{5 0 0}$ meter terjadi lebih besar dibandingkan diluar area radius $\mathbf{5 0 0}$ meter dari kampus Unsoed Purwokerto.

\subsection{Analisis Kepadatan Bangunan}

Analisis kepadatan bangunan dilakukan untuk melihat tingkat kepadatan bangunan di kawasan sekitar perguruan tinggi Unsoed Purwokerto. Pada periode waktu 10 tahun dari tahun 2003 sampai dengan tahun 2013, tingkat kepadatan di kawasan sekitar perguruan tinggi Unsoed Purwokerto secara menyeluruh maupun dalam radius 500 meter dari kampus Unsoed Purwokerto dikategorikan masih rendah sehingga kepadatan bangunan yang ada masih dapat diklasifikasikan ke dalam kriteria kepadatan bangunan yang baik.

Tabel 10. Kepadatan Bangunan Di Kawasan Sekitar Perguruan Tinggi Unsoed Purwokerto Tahun 2003 sampai Tahun 2013 (Hasil Analisis, 2015)

\begin{tabular}{|c|c|c|c|c|c|c|c|c|c|}
\hline \multirow[b]{2}{*}{ Kelurahan } & \multirow{2}{*}{$\begin{array}{c}\text { Luas } \\
\text { Wilayah }\end{array}$} & \multicolumn{2}{|c|}{ Tahun 2003} & \multicolumn{2}{|c|}{ Tahun 2008} & \multicolumn{2}{|c|}{ Tahun 2013} & \multicolumn{2}{|c|}{ Perubahan } \\
\hline & & $\begin{array}{c}\text { Luas } \\
\text { Bangunan }\end{array}$ & $\begin{array}{l}\text { Kepadatan } \\
\text { Bangunan }\end{array}$ & $\begin{array}{l}\text { Luas } \\
\text { Bangunan }\end{array}$ & $\begin{array}{l}\text { Kepadatan } \\
\text { Bangunan }\end{array}$ & $\begin{array}{c}\text { Luas } \\
\text { Bangunan }\end{array}$ & $\begin{array}{l}\text { Kepadatan } \\
\text { Bangunan }\end{array}$ & $\begin{array}{l}2008- \\
2003\end{array}$ & $\begin{array}{l}2013- \\
2008\end{array}$ \\
\hline Bancarkembar & $1.330 .483,089$ & $381.250,81$ & $28.66 \%$ & $404.324,86$ & $30.39 \%$ & $418.042,01$ & $31.42 \%$ & $1.73 \%$ & $1.03 \%$ \\
\hline Sumampir & $1.439 .582,229$ & $224.409,31$ & $15.59 \%$ & $301.423,06$ & $20.94 \%$ & $318.09,41$ & $22.09 \%$ & $5.23 \%$ & $1.15 \%$ \\
\hline Pabuwaran & $1.486 .531,231$ & $153.832,87$ & $10.35 \%$ & $186.311,70$ & $12.53 \%$ & $211.985,00$ & $14.26 \%$ & $2.18 \%$ & $1.73 \%$ \\
\hline Grendeng & $1.345 .355,833$ & $305.302,82$ & $22.69 \%$ & $350.852,28$ & $26.08 \%$ & $378.719,01$ & $28.15 \%$ & $3.39 \%$ & $2.07 \%$ \\
\hline Karangwangkal & $730.295,698$ & $109.694,40$ & $15.02 \%$ & $117.182,24$ & $16.05 \%$ & $138.318,68$ & $18.94 \%$ & $1.03 \%$ & $2.89 \%$ \\
\hline Total Luas & $6.332 .248,081$ & $1.174 .490,20$ & $18.55 \%$ & $1.360 .094,13$ & $21.48 \%$ & $1.465 .074,11$ & $23.14 \%$ & $2.93 \%$ & $1.66 \%$ \\
\hline
\end{tabular}


Tabel 11. Kepadatan Bangunan Di Kawasan Sekitar Perguruan Tinggi Unsoed Purwokerto Radius $500 \mathrm{~m}$ dari Perguruan Tinggi Unsoed Purwokerto Tahun 2003 sampai Tahun 2013 (Hasil Analisis, 2015)

\begin{tabular}{|c|c|c|c|c|c|c|c|c|c|}
\hline \multirow[b]{2}{*}{ Kelurahan } & \multirow{2}{*}{$\begin{array}{c}\text { Luas } \\
\text { Wilayah }\end{array}$} & \multicolumn{2}{|c|}{ Tahun 2003} & \multicolumn{2}{|c|}{ Tahun 2008} & \multicolumn{2}{|c|}{ Tahun 2013} & \multicolumn{2}{|c|}{ Perubahan } \\
\hline & & $\begin{array}{l}\text { Luas } \\
\text { Bangunan }\end{array}$ & $\begin{array}{l}\text { Kepadatan } \\
\text { Bangunan }\end{array}$ & $\begin{array}{l}\text { Luas } \\
\text { Bangunan }\end{array}$ & $\begin{array}{l}\text { Kepadatan } \\
\text { Bangunan }\end{array}$ & $\begin{array}{l}\text { Luas } \\
\text { Bangunan }\end{array}$ & $\begin{array}{l}\text { Kepadatan } \\
\text { Bangunan }\end{array}$ & $\begin{array}{l}2008- \\
2003\end{array}$ & $\begin{array}{l}2013- \\
2008\end{array}$ \\
\hline Bancarkembar & $481.892,169$ & 119.216,199 & $24.74 \%$ & $131.000,010$ & $27.18 \%$ & $141.881,354$ & $29.44 \%$ & $2.45 \%$ & $2.26 \%$ \\
\hline Sumampir & $271.200,738$ & $75.550,012$ & $27.86 \%$ & $89.803,626$ & $33.11 \%$ & $91.707,971$ & $33.82 \%$ & $5.26 \%$ & $0.70 \%$ \\
\hline Pabuwaran & $216.938,069$ & $20.710,581$ & $9.55 \%$ & $25.830,033$ & $11.91 \%$ & $31.792,169$ & $14.65 \%$ & $2.36 \%$ & $2.75 \%$ \\
\hline Grendeng & $1.167 .494,623$ & $252.586,119$ & $21.63 \%$ & $290.686,437$ & $24.90 \%$ & $315.240,031$ & $27.00 \%$ & $3.26 \%$ & $2.10 \%$ \\
\hline Karangwangkal & $727.855,062$ & $109.694,395$ & $15.07 \%$ & $117.182,237$ & $16.10 \%$ & $138.273,043$ & $19.00 \%$ & $1.03 \%$ & $2.90 \%$ \\
\hline Total Luas & $2.865 .380,661$ & $577.757,306$ & $20.16 \%$ & $654.502,343$ & $22.84 \%$ & $718.894,568$ & $25.09 \%$ & $2.68 \%$ & $2.25 \%$ \\
\hline
\end{tabular}

Peningkatan kepadatan bangunan yang terjadi di kawasan sekitar perguruan tinggi Unsoed Purwokerto secara menyeluruh maupun pada radius 500 meter dari perguruan tinggi Unsoed Purwokerto tahun 2003 sampai tahun 2008 terbesar di Kelurahan Sumampir, diikuti oleh Kelurahan Grendeng. Sedangkan pada tahun 2008 sampai dengan tahun 2013 secara menyeluruh pada kawasan sekitar perguruan tinggi Unsoed Purwokerto peningkatan kepadatan bangunan terjadi di Kelurahan Karangwangkal dan diikuti oleh Kelurahan Grendeng dan pada radius 500 meter dari kampus Unsoed Purwokerto terjadi di Kelurahan Karangwangkal yang diikuti oleh Kelurahan Pabuwaran. Hal ini menunjukkan bahwa di kawasan sekitar perguruan tinggi Unsoed Purwokerto baik secara keseluruhan maupun dalam radius 500 meter dari kampus Unsoed Purwokerto selama periode waktu dari tahun 2003 sampai dengan tahun 2013 terjadi peningkatan kepadatan, tetapi peningkatan kepadatan bangunan yang terjadi masih relatif rendah, sehingga masih sangat memungkinkan apabila terjadi peningkatan luas bangunan dibandingkan dengan luas wilayahnya.

Berdasarkan data hasil perhitungan kepadatan bangunan di kawasan sekitar perguruan tinggi Unsoed Purwokerto, Kelurahan Bancarkembar yang memiliki kepadatan yang paling tinggi dibanding kelurahan yang lain dan mendekati ke dalam kategori kepadatan sedang yaitu antara $40 \%-60 \%$. Peningkatan kepadatan bangunan rata-rata pertahun pada kawasan secara menyeluruh sebesar $4,59 \%$ sedangkan pada area radius 500 meter dari kampus Unsoed Purwokerto sebesar 4,93\%.

\subsection{Analisis Figure/Ground}

Analisis Figure/Ground dilakukan untuk mengidentifikasi pola perkembangan dan perubahan morfologi kawasan sekitar perguruan tinggi Unsoed Purwokerto dengan melihat tekstur dan pola-pola tata ruang perkotaan dan tatanan keteraturan massa atau ruang kawasan. Analisis figure ground menggunakan dua elemen yaitu elemen solid dan void, figure melambangkan massa yang dibangun (solid yang ditunjukkan dengan warna hitam) dan Ground untuk semua ruang di luar massa itu (void yang ditunjukkan dengan warna putih).

Pola perkembangan kawasan disekitar perguruan tinggi Unsoed Purwokerto pada radius 500 meter dari kampus dari tahun 2003 sampai tahun 2013 di Kelurahan Grendeng dan Karangwangkal membentuk fisik kota seperti gurita, hal ini disebabkan oleh tersedianya beberapa jaringan jalan ke semua arah di lingkungan kampus Unsoed. Hal ini menunjukkan bahwa jalur transportasi sangat dominan tidak saja hanya satu jalur melainkan terdapat beberapa jalur ke arah sekitar lingkungan kampus Unsoed. Kawasan di Kelurahan Bancarkembar, Sumampir, dan Pabuwaran dihubungkan oleh jalan kolektor primer dengan kampus Unsoed, dimana sepanjang jalan kolektor primer cenderung difungsikan untuk perdagangan dan jasa sehingga pola perkembangannya cenderung linear sepanjang jalur jalan kolektor primer yang merupakan satu jalur panjang memotong kawasan sekitar kawasan perguruan tinggi Unsoed Purwokerto sedangkan di jalan-jalan lingkungan kecenderungan pola perkembangan bangunan mengelompok membentuk suatu cluster tertentu. 
Gambar 7. Analisis Figure / Ground Kawasan Sekitar Perguruan Tinggi Unsoed Purwokerto Radius 500 Meter Tahun 2003 (Hasil Analisis, 2015)

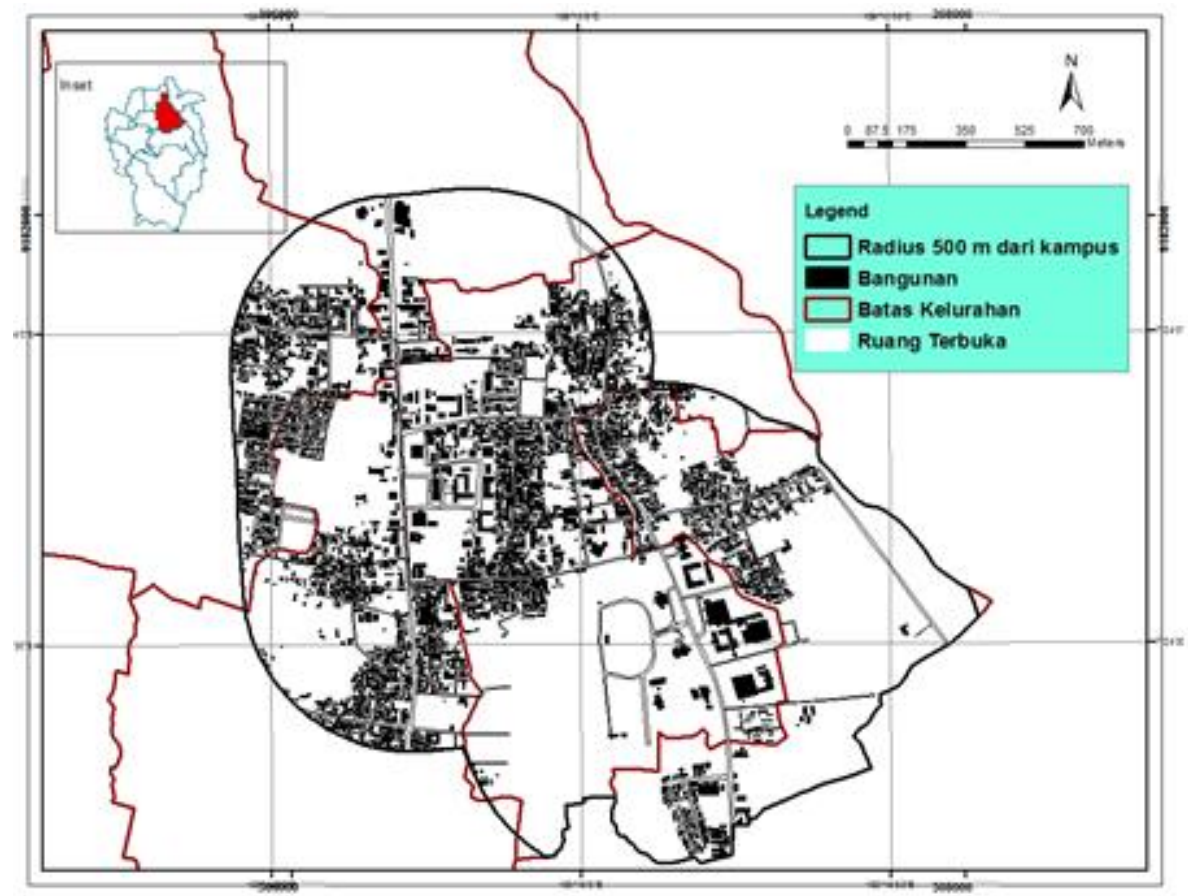

Gambar 8. Analisis Figure / Ground Kawasan Sekitar Perguruan Tinggi Unsoed Purwokerto Radius 500 Meter Tahun 2013 (Hasil Analisis, 2015)

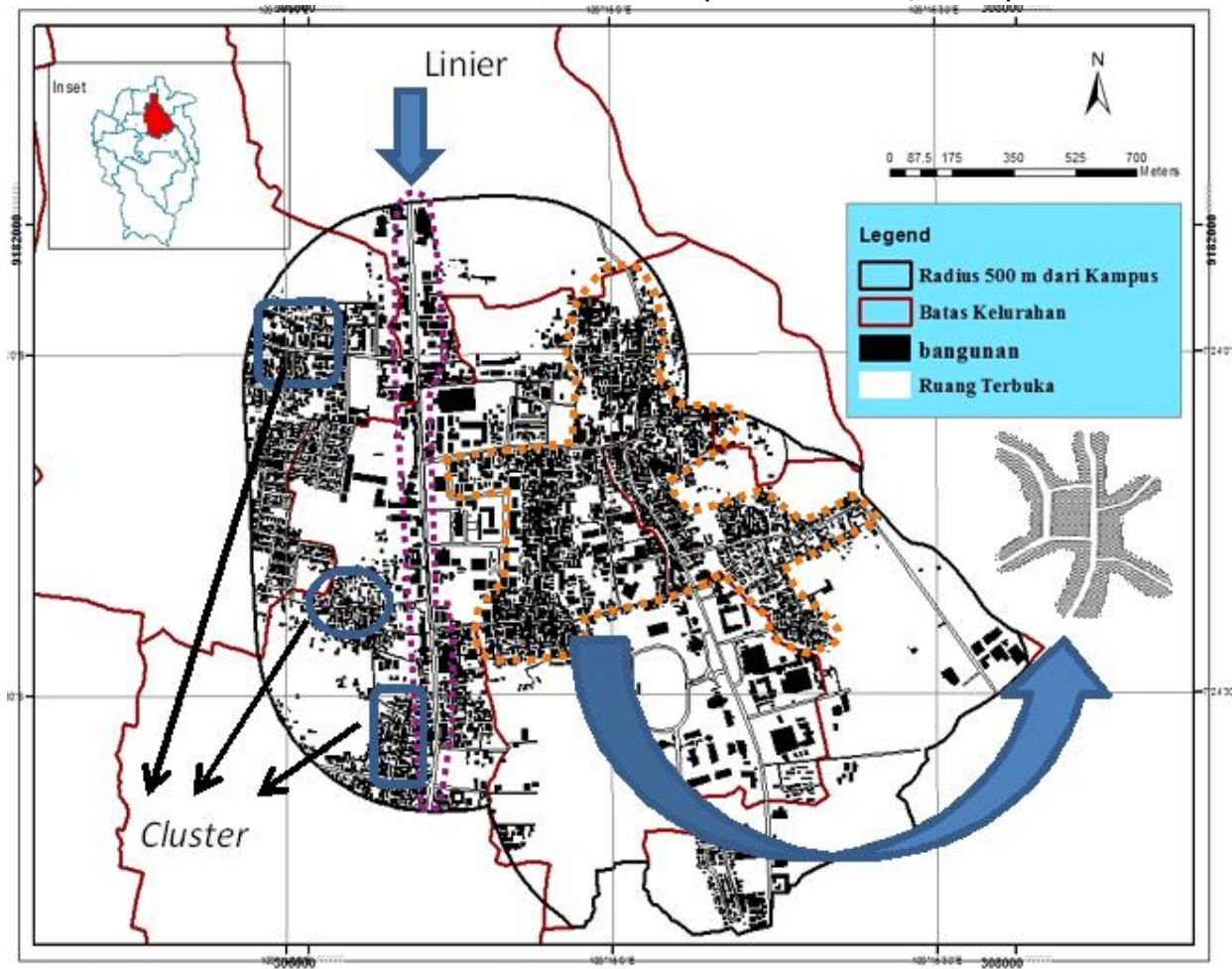

Pola perkembangan dan perubahan morfologi kawasan sekitar perguruan tinggi Unsoed Purwokerto secara menyeluruh di lihat dari pola tekstur kawasannya dengan analisis figure ground dapat disimpulkan bahwa sebagian besar pola ruang kawasannya cenderung homogen dan mengelompok di beberapa lokasi serta menyebar mengikuti arah jalur transportasi ke kawasan pinggiran terutama pada bagian utara yaitu Kelurahan Pabuwaran dan bagian Barat yaitu Kelurahan Sumampir. 
Gambar 8. Analisis Figure / Ground Kawasan Sekitar Perguruan Tinggi Unsoed Purwokerto Tahun 2003 dan 2013 (Hasil Analisis, 2015)

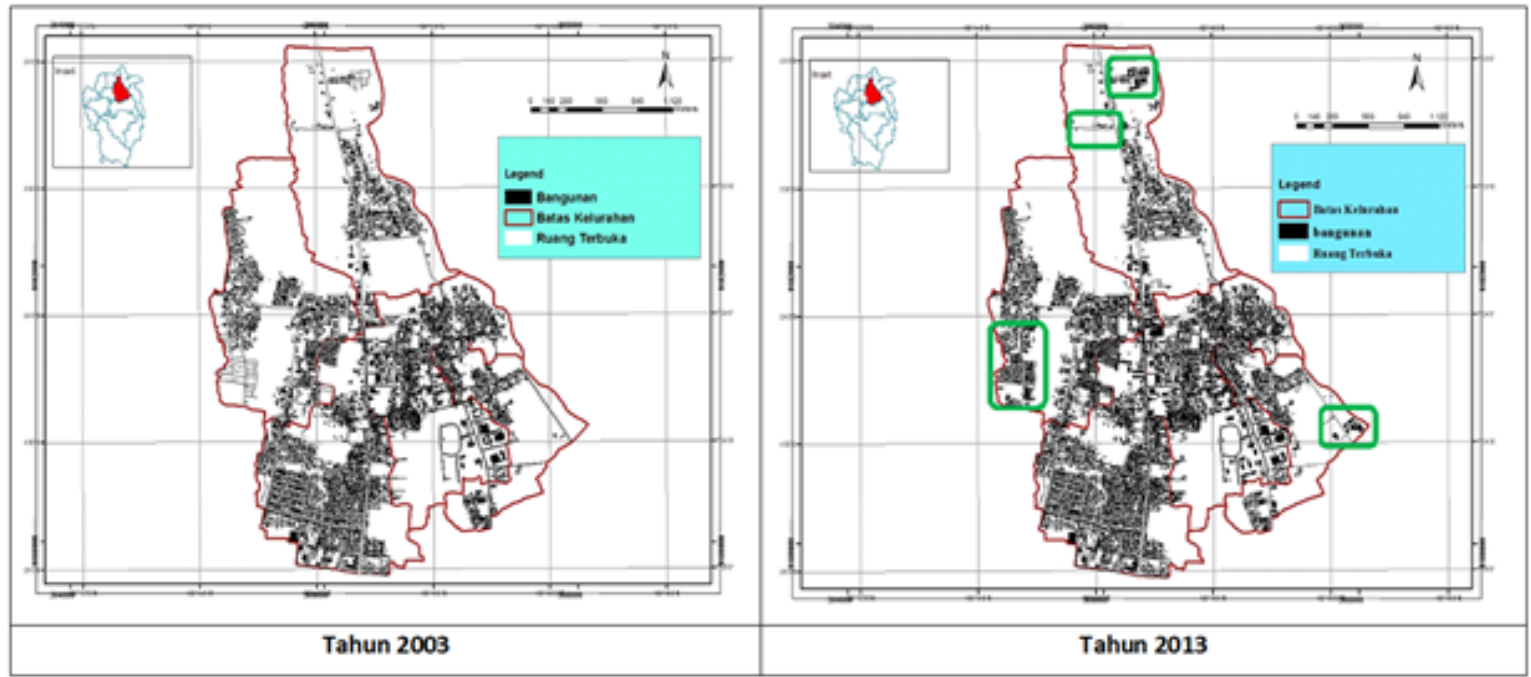

\subsection{Analisis Pengaruh dan Pembuktian Hipotesis}

Analisis pengaruh dan pembuktian hipotesis dilakukan untuk melihat dan membuktikan kebenaran bahwa keberadaan perguruan tinggi Unsoed Purwokerto mempengaruhi perubahan morfologi kawasan di sekitarnya. Pembuktian pengaruh keberadaan perguruan tinggi Unsoed Purwokerto terhadap perubahan morfologi kawasan di sekitarnya dilakukan dengan cara penyebaran kuesoner dan visual foto pada bangunan yang dibangun dari tahun 2003 sampai tahun 2013 di kawasan sekitar perguruan tinggi Unsoed Purwokerto pada radius 500 meter dari 2 lokasi kampus Unsoed di Kelurahan Grendeng Kecamatan Purwokerto Utara sesuai dengan penentuan sampel yang telah dilakukan.

Penentuan bangunan yang akan dijadikan sebagai sampel adalah bangunan yang dibangun di sekitar perguruan tinggi Unsoed Purwokerto pada radius 500 meter dari tahun 2003 sampai tahun 2013 maupun yang dibangun sebelum tahun 2003 tetapi dalam waktu 10 tahun dari tahun 2003 sampai tahun 2013 telah mengalami perubahan bentuk atau perluasan bangunan yang didasarkan dari hasil analisis citra. Oleh karena itu yang dijadikan sebagai responden pada penelitian ini adalah pemilik bangunan dari bangunan yang dijadikan sampel penelitian.

Penyebaran kuesioner dilakukan di 5 (lima) kelurahan yang ada di sekitar perguruan tinggi unsoed pada radius 500 meter dari kampus sebanyak 107 responden yang terdiri dari Kelurahan Bancarkembar sebanyak 25 responden, Kelurahan Sumampir 19 responden, Kelurahan Pabuwaran 5 responden, Kelurahan Grendeng 33 responden dan Kelurahan Karangwangkal sebanyak 25 responden. Peta sebaran responden pada kawasan sekitar perguruan tinggi Unsoed Purwokerto radius 500 meter dari kampus Unsoed dapat dilihat pada gambar 9.

Pemilik bangunan di kawasan sekitar perguruan tinggi Unsoed Purwokerto radius $500 \mathrm{~m}$ dari kampus Unsoed Purwokerto sebagian besar merupakan penduduk pendatang yang tinggal maupun yang hanya membangun bangunan sebagai pemilik bangunan

Tabel 12. Analisa Status Penduduk dan Kedatangan Pemilik Bangunan

Di Kawasan Sekitar Unsoed Purwokerto (Hasil Analisis, 2015)

\begin{tabular}{|c|c|c|c|c|c|c|}
\hline \multirow{2}{*}{ Kelurahan } & \multirow{2}{*}{$\begin{array}{c}\text { Jumlah } \\
\text { Bangunan }\end{array}$} & \multicolumn{2}{|c|}{ Penduduk } & \multicolumn{3}{|c|}{ Tahun Kedatangan / kepindahan } \\
\hline & & Pendatang & Asli & $<=$ Thn. 2003 & $<=$ Thn. 2008 & $<=$ Thn. 2013 \\
\hline Bancarkembar & 1.601 & $11,3 \%$ & $12,3 \%$ & $0,0 \%$ & $6,4 \%$ & $12,8 \%$ \\
\hline Pabuwaran & 166 & $2,5 \%$ & $0,0 \%$ & $0,0 \%$ & $0,8 \%$ & $3,3 \%$ \\
\hline Sumampir & 1.083 & $11,8 \%$ & $4,2 \%$ & $2,8 \%$ & $12,8 \%$ & $4,3 \%$ \\
\hline Grendeng & 2.287 & $14,3 \%$ & $19,4 \%$ & $3,5 \%$ & $6,9 \%$ & $13,8 \%$ \\
\hline Karangwangkal & 1.635 & $19,3 \%$ & $4,8 \%$ & $13,0 \%$ & $4,9 \%$ & $14,7 \%$ \\
\hline Jumlah & 6.772 & $59,2 \%$ & $40,8 \%$ & $19,3 \%$ & $31,8 \%$ & $48,8 \%$ \\
\hline Total Persentase & & \multicolumn{2}{|c|}{$100 \%$} & \multicolumn{3}{|c|}{$100 \%$} \\
\hline
\end{tabular}


Gambar 9. Peta Sebaran Responden pada Radius 500 Meter dari Perguruan Tinggi Unsoed Purwokerto (Hasil Analisis, 2015)

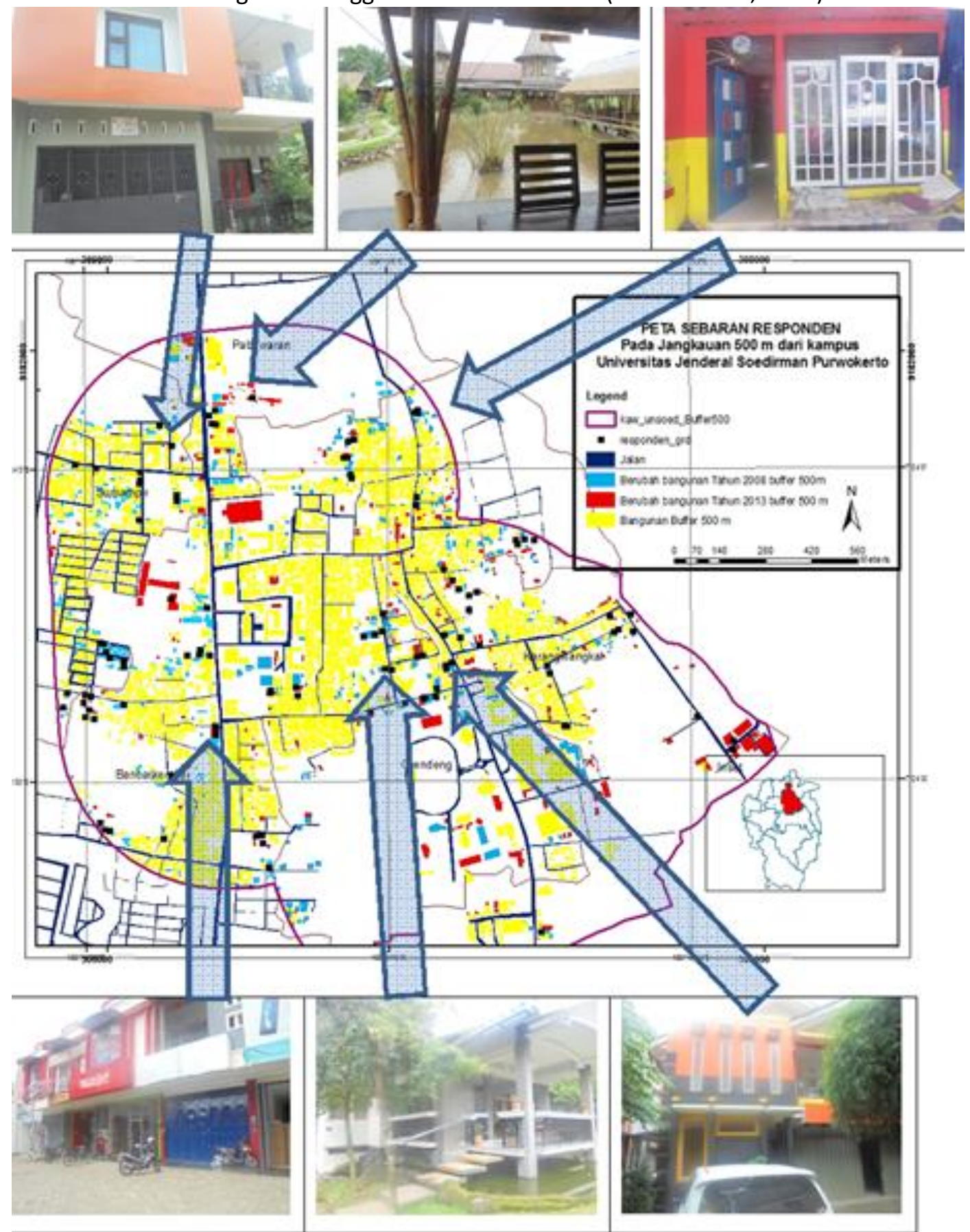

Tabel 13. Analisa Alasan Pemilihan Lokasi Bangunan (Hasil Analisis, 2015)

\begin{tabular}{|c|c|c|c|c|c|}
\hline \multirow{2}{*}{ Kelurahan } & \multirow{2}{*}{$\begin{array}{c}\text { Jumlah } \\
\text { Bangunan }\end{array}$} & \multicolumn{2}{|c|}{ Alasan Pemilihan Lokasi } & \multicolumn{2}{|c|}{ Pengaruh Keberadaan Unsoed } \\
\hline & & dekat Unsoed & lainnya & Ya & Tidak \\
\hline Bancarkembar & 1.601 & $16,1 \%$ & $7,6 \%$ & $18,0 \%$ & $5,7 \%$ \\
\hline Pabuwaran & 166 & $2,5 \%$ & $0,0 \%$ & $2,5 \%$ & $0,0 \%$ \\
\hline Sumampir & 1.083 & $10,1 \%$ & $5,9 \%$ & $11,8 \%$ & $4,2 \%$ \\
\hline Grendeng & 2.287 & $26,6 \%$ & $7,2 \%$ & $29,7 \%$ & $4,1 \%$ \\
\hline Karangwangkal & 1.635 & $15,5 \%$ & $8,7 \%$ & $19,3 \%$ & $4,8 \%$ \\
\hline Jumlah & 6.772 & $70,7 \%$ & $29,3 \%$ & $81,2 \%$ & $18,8 \%$ \\
\hline Total Persentase & & \multicolumn{2}{|c|}{$100 \%$} & \multicolumn{2}{|c|}{$100 \%$} \\
\hline
\end{tabular}


Berdasarkan hasil kuesioner bahwa alasan pemilihan lokasi pada radius $500 \mathrm{~m}$ dari kampus Unsoed sebagian besar karena alasan lokasinya dekat dengan Unsoed sedangkan alasan lain adalah karena lokasinya yang strategis, merupakan tanah waris maupun karena dekat dengan orangtua. Walaupun beberapa alasan utamanya bukan karena lokasinya dekat dengan Unsoed, tetapi keberadaan perguruan tinggi Unsoed Purwokerto sebagian besar merupakan salah satu alasan yang mempengaruhi pemilihan lokasi bangunan tersebut. Sehingga keberadaan Unsoed sangat mempengaruhi peningkatan bangunan yang dibangun di kawasan sekitar kampus pada radius 500 meter.

Bangunan yang didirikan di kawasan sekitar kampus Unsoed pada radius $500 \mathrm{~m}$ dari kampus Unsoed sebagian besar penggunaan lahan sebelumnya adalah tanah kosong dan sawah atau tegalan. Hal ini menunjukan bahwa kecenderungan perubahan penggunaan lahannya adalah dari lahan kosong dan lahan pertanian menjadi lahan terbangun atau bangunan.

Tabel 14. Analisa Penggunaan Lahan Sebelumnya (Hasil Analisis, 2015)

\begin{tabular}{lccccc}
\hline \multirow{2}{*}{ Kelurahan } & Jumlah & \multicolumn{4}{c}{ Penggunaan Lahan Sebelumnya } \\
\cline { 3 - 6 } & Bangunan & Permukiman & TK & S/T & Bdn Air \\
\hline Bancarkembar & 1.601 & $0,0 \%$ & $13,2 \%$ & $8,5 \%$ & $1,9 \%$ \\
\hline Pabuwaran & 166 & $0,5 \%$ & $1,0 \%$ & $1,0 \%$ & $0,0 \%$ \\
\hline Sumampir & 1.083 & $0,8 \%$ & $5,9 \%$ & $9,3 \%$ & $0,0 \%$ \\
\hline Grendeng & 2.287 & $2,0 \%$ & $14,3 \%$ & $17,4 \%$ & $0,0 \%$ \\
\hline Karangwangkal & 1.635 & $3,9 \%$ & $11,6 \%$ & $8,7 \%$ & $0,0 \%$ \\
\hline Jumlah & 6.772 & $\mathbf{7 , 2 \%}$ & $\mathbf{4 6 , 0 \%}$ & $\mathbf{4 4 , 8 \%}$ & $\mathbf{1 , 9 \%}$ \\
\hline Total Persentase & & \multicolumn{5}{c}{$\mathbf{1 0 0 \%}$} \\
\hline
\end{tabular}

Bangunan di kawasan sekitar perguruan tinggi Unsoed Purwokerto pada radius $500 \mathrm{~m}$ dari kampus Unsoed sebagian besar difungsikan untuk tempat kos dan Usaha yaitu sebesar $71,1 \%$, sedangkan untuk tempat tinggal saja sebesar $28,9 \%$. Bangunan yang difungsikan sebagai tempat kos, penghuninya $100 \%$ merupakan mahasiswa maupun pegawai di perguruan tinggi Unsoed Purwokerto dan bangunan yang difungsikan untuk usaha, usahanya juga $100 \%$ merupakan usaha yang mendukung aktivitas mahasiswa.

Tabel 15. Analisa Penggunaan Bangunan dari Tahun 2003 sampai Tahun 2013 pada Kawasan Sekitar Perguruan Tinggi Unsoed Purwokerto Radius 500 m dari Kampus (Hasil Analisis, 2015)

\begin{tabular}{|c|c|c|c|c|c|c|c|c|c|c|c|c|c|c|c|}
\hline \multirow[b]{2}{*}{ Kelurahan } & \multirow{2}{*}{$\begin{array}{c}\text { Jumlah } \\
\text { Bangunan }\end{array}$} & \multicolumn{7}{|c|}{ Fungsi Bangunan } & \multicolumn{3}{|c|}{ Status Kos } & \multicolumn{2}{|c|}{$\begin{array}{c}\text { Mahasiswa / } \\
\text { Pegawai Unsoed }\end{array}$} & \multicolumn{2}{|c|}{$\begin{array}{l}\text { Usaha mendukung } \\
\text { aktivitas mahasiswa }\end{array}$} \\
\hline & & TT & $u$ & Kos & TT \& U & $\begin{array}{l}\text { TT \& } \\
\text { Kos }\end{array}$ & Kos \& U & $\begin{array}{l}\text { TT, Kos, } \\
\& U\end{array}$ & M & $\mathbf{P}$ & $M \& P$ & $\mathrm{Y}$ & $\mathbf{T}$ & $\mathrm{Y}$ & $\mathbf{T}$ \\
\hline Bancarkembar & 1.601 & $8.5 \%$ & $6.6 \%$ & $3.8 \%$ & $0.9 \%$ & $0.9 \%$ & $0.9 \%$ & $1.9 \%$ & $16.1 \%$ & $0.0 \%$ & $0.0 \%$ & $16.1 \%$ & $0.0 \%$ & $31.2 \%$ & $0.0 \%$ \\
\hline Pabuwaran & 166 & $0.0 \%$ & $2.0 \%$ & $0.0 \%$ & $0.0 \%$ & $0.0 \%$ & $0.0 \%$ & $0.5 \%$ & $1.0 \%$ & $0.0 \%$ & $0.0 \%$ & $1.0 \%$ & $0.0 \%$ & $7.3 \%$ & $0.0 \%$ \\
\hline Sumampir & 1.083 & $8.4 \%$ & $2.5 \%$ & $2.5 \%$ & $0.8 \%$ & $1.7 \%$ & $0.0 \%$ & $0.0 \%$ & $7.2 \%$ & $0.0 \%$ & $1.8 \%$ & $9.0 \%$ & $0.0 \%$ & $10.1 \%$ & $0.0 \%$ \\
\hline Grendeng & 2.287 & $7.2 \%$ & $6.1 \%$ & $7.2 \%$ & $4.1 \%$ & $6.1 \%$ & $0.0 \%$ & $3.1 \%$ & $34.8 \%$ & $0.0 \%$ & $0.0 \%$ & $34.8 \%$ & $0.0 \%$ & $39.8 \%$ & $0.0 \%$ \\
\hline Karangwangkal & 1.635 & $4.8 \%$ & $0.0 \%$ & $6.8 \%$ & $1.0 \%$ & $8.7 \%$ & $0.0 \%$ & $1.9 \%$ & $34.9 \%$ & $0.0 \%$ & $4.1 \%$ & $39.1 \%$ & $0.0 \%$ & $11.6 \%$ & $0.0 \%$ \\
\hline Jumlah & 6.772 & $28.9 \%$ & $17.2 \%$ & $20.2 \%$ & $6.8 \%$ & $17.5 \%$ & $1.0 \%$ & $7.4 \%$ & $94.1 \%$ & $0.0 \%$ & $5.9 \%$ & $100.0 \%$ & $0.0 \%$ & $100.0 \%$ & $0.0 \%$ \\
\hline \multicolumn{2}{|c|}{ Total Prosentase } & & & & $100 \%$ & & & & & $100 \%$ & & 10 & & 10 & \\
\hline
\end{tabular}

Berdasarkan analisis pembuktian pengaruh diatas terdapat perbedaan yang signifikan antara kelurahan yang lokasi kampus Unsoed berada dan kelurahan di luar kampus Unsoed. Oleh karena itu untuk memperjelas pengaruh keberadaan Unsoed terhadap perubahan morfologi kawasan di sekitarnya pada radius 500 meter dari kampus akan dilakukan analisis lebih lanjut dengan membagi kawasan sekitar kampus Unsoed Purwokerto yang terdiri dari 5 kelurahan menjadi dua kawasan yaitu kawasan kelurahan lokasi kampus Unsoed dan kawasan kelurahan diluar lokasi kampus Unsoed. Kawasan kelurahan lokasi kampus Unsoed terdiri dari 2 kelurahan yaitu Kelurahan Grendeng dan Kelurahan Karangwangkal, sedangkan kawasan kelurahan di luar lokasi kampus Unsoed terdiri dari 3 kelurahan yaitu Kelurahan Bancarkembar, Sumampir dan Pabuwaran. 
Kawasan kelurahan lokasi kampus Unsoed dengan kawasan diluar lokasi kampus Unsoed kuatnya pengaruh keberadaan perguruan tinggi Unsoed dapat dipengaruhi oleh kedekatan jarak dan kemudahan transportasi.

Kawasan kelurahan lokasi kampus berada diantara lokasi kampus di Kelurahan Grendeng dan kampus yang diperbatasan Kelurahan Grendeng dan Karangwangkal sehingga jarak ke lokasi kampus lebih dekat daripada kawasan kelurahan di luar lokasi kampus yang hanya masuk ke dalam radius 500 meter dari kampus Unsoed di Kelurahan Grendeng. Kemudahan transportasi dapat dilihat dengan ketersediaan jaringan jalan yang memadai di kawasan tersebut. Di kawasan kelurahan lokasi kampus Unsoed sudah tersedia banyak jalan lingkungan sehingga untuk ke pusat kegiatan dalam hal ini adalah kampus Unsoed tersedia banyak jalan alternatif yang memudahkan dan mempercepat transportasi ke kampus Unsoed dengan tanpa hambatan adanya traffic light sehingga waktu tempuhnya lebih cepat.

Jaringan jalan di kawasan kelurahan di luar lokasi kampus Unsoed dihubungkan oleh jalan kolektor primer dan jalan lingkungan. Jalan ini memiliki intensitas frekuensi lalu-lintas yang cukup tinggi. Di kawasan kelurahan di luar lokasi kampus Unsoed sudah tersedia banyak jalan lingkungan tetapi untuk ke pusat kegiatan dalam hal ini adalah kampus Unsoed harus melalui jalan kolektor primer sehingga jalan alternatif yang memudahkan dan mempercepat transportasi ke kampus Unsoed tidak tersedia, disamping itu juga terdapat beberapa hambatan adanya traffic light sehingga menambah waktu yang harus tempuh untuk mencapai kampus Unsoed.

Lebih jelasnya dapat dilihat pada gambar 4.26. Pada gambar tersebut dapat dilihat lingkaran merah putus-putus yang berada di Kelurahan Grendeng dan Karangwangkal yang masuk ke radius 500 meter dari kedua kampus tersebut dengan jaringan jalan yang mendukung kepadatan bangunannya terlihat jelas. Lingkaran coklat putus-putus di Kelurahan Karangwangkal merupakan jarak terdekat dari kampus Unsoed di perbatasan Kelurahan Grendeng dan Karangwangkal dengan jaringan jalan yang mendukung sehingga terlihat kepadatan bangunan yang jelas dan mengelompok sepanjang jalan lingkungan. Sehingga dapat ditarik kesimpulan bahwa berdasarkan aksesibilitas yang dilihat dari kedekatan jarak dan kemudahan transportasi, kawasan kelurahan lokasi kampus Unsoed mempunyai aksesibilitas yang lebih tinggi dibanding kawasan kelurahan di luar lokasi kampus. Hal ini menjadi daya tarik yang kuat untuk pendatang mendirikan bangunan di kawasan tersebut dibanding di kawasan kelurahan di luar lokasi kampus Unsoed. 
Gambar 10. Analisis Kedekatan Jarak dan Kemudahan Transportasi Di Kawasan Sekitar Perguruan Tinggi Unsoed Purwokerto (Hasil Analisis, 2015)
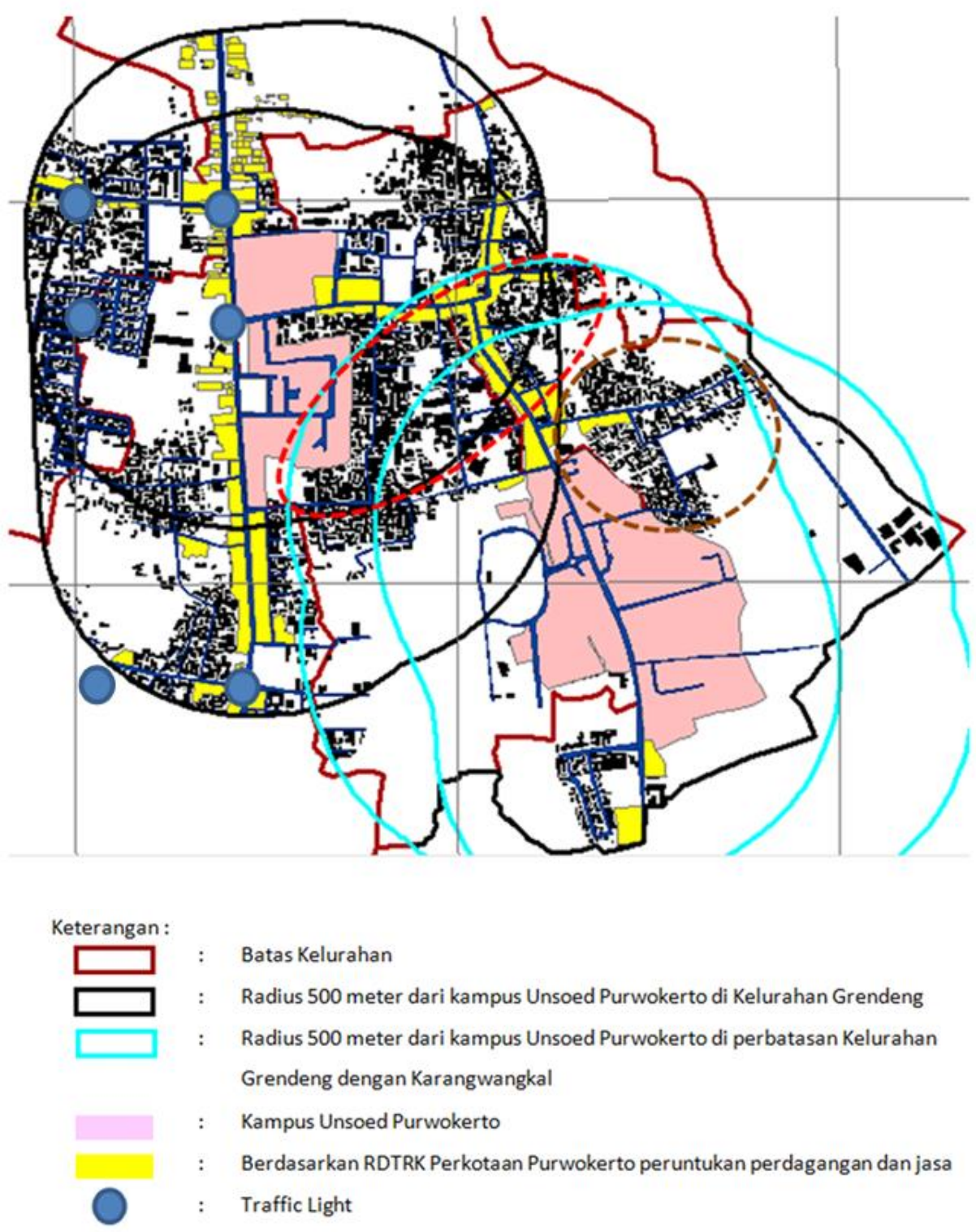

\section{KESIMPULAN}

Berdasarkan hasil analisis di atas, dapat ditarik kesimpulan bahwa keberadaan perguruan tinggi Unsoed Purwokerto telah mempengaruhi secara signifikan (lebih dari $80 \%$ ) terhadap terjadinya perubahan morfologi kawasan di sekitar perguruan tinggi Unsoed Purwokerto. Hal ini dapat dibuktikan dengan:

1. Perubahan penutupan/penggunaan lahan pertanian menurun sebesar $7,4 \%$ dari luas pertanian pada radius 500 meter pada tahun 2003. Sedangkan perubahan penutupan/penggunaan lahan terbangun meningkat sebesar 18,3\% dari luas bangunan pada radius 500 meter pada tahun 2003.

2. Kepadatan bangunan rata-rata per tahun meningkat $4,93 \%$

3. Pola perkembangan kawasan yang cenderung mengelompok di sekitar jalan-jalan lingkungan, sepanjang jalan kolektor primer cenderung pola perkembangan linier dan perkembangan kawasan yang membentuk seperti gurita di lingkungan Kelurahan Grendeng dan Karangwangkal.

4. Berdasarkan hasil kuesioner membuktikan bahwa keberadaan Unsoed merupakan salah satu alasan yang mempengaruhi dalam pemilihan lokasi didirikannya bangunan sebesar $81,2 \%$ dari jumlah bangunan di kawasan sekitar perguruan tinggi Unsoed Purwokerto pada radius $500 \mathrm{~m}$ dari kampus Unsoed Purwokerto dengan sebagian besar penggunaan bangunannya diperuntukan untuk tempat kos dan usaha barang dan jasa yang mendukung aktivitas mahasiswa di sekitar perguruan tinggi Unsoed Purwokerto. 
5. Pengaruh keberadaan perguruan tinggi Unsoed terhadap perubahan morfologi kawasan di sekitarnya terutama pada radius 500 meter dari kampus, di Kelurahan Grendeng dan Karangwangkal dimana lokasi kampus Unsoed berada pengaruhnya lebih besar dibandingkan dengan kelurahan yang diluar lokasi kampus Unsoed yaitu Kelurahan Bancarkembar, Sumampir dan Pabuwaran. Hal ini disebabkan karena aksesibilitas ke kampus Unsoed di Kelurahan Grendeng dan Karangwangkal lebih tinggi dibanding dengan 3 kelurahan yang lain.

\section{DAFTAR PUSTAKA}

Araya Yikalo H, et al. (2010). Analysis and Modeling of Urban Land Cover Change in Setubal and Sesimba, Portugal. Remote Sensing 2010, 2, 1549-1563; DOI: 10.3390/rs2061549. [Online]. Tersedia di www.mdpi.com/journal/remotesensing. Diakses tanggal 26 Mei 2014.

Anderson, JR et al. (1976). A Land Use And Land Cover Classification System For Use With Remote Sensor Data. Conversion to Digital 2001. Geological Survey Professional Paper 1964, United States Government Printing Office, Washington. [online]. Tersedia di http://landcover.usgs.gov/pdf/ anderson.pdf. Diakses pada tanggal 11 Oktober 2014.

Du, Xindong et al. (2014). Spatial Pattern of Land-Use Change and Its Driving Force in Jiangsu Province. International Journal of Environmental Research and Public Health, Vol. 11, pp.3215-3232.

$\mathrm{Hu}$, Dan et al. (2008). Analyzing Land Use Changes in the Metropolitan Jilin City of Northeastern China Using Remote Sensing and GIS. Sensors 2008, 8, 5449-5465; DOI: 10.3390/s8095449. [Online]. Tersedia di www.mdpi.org/sensors. Diakses tanggal 26 Mei 2014.

Martinez, Susana and Danilo Mollicone. (2012). "From Land Cover to Land Use : A Methodology to Assess Land Use from Remote Sensing Data". Remote Sensing 2012, 4, 1024-1045; DOI: 10.3390/rs4041024. [Online]. Tersedia di www.mdpi.com/journal/remotesensing. Diakses tanggal 26 Mei 2014.

Ningal, Tine et al. (2006). "Land Use Change and Population Growth in The Morobe Province of Papua New Guinea Between 1975 and 2000". Journal of Environmental Management 87 (2008) 117-124 [Online]. Tersedia di www.elsevier.com/locate/jenvman. Diakses tanggal 9 Juni 2011.

Peng, Jian et al. (2008). Rural Land Use Change during 1986-2002 in Lijiang, China Based on Remote Sensing and GIS Data. Sensors 2008, 8, 8201-8223; DOI: 10.3390/s8128201. [Online]. Tersedia di www.mdpi.org/sensors. Diakses tanggal 26 Mei 2014.

Reis, Selcuk. (2008). Analyzing Land Use/Land Cover Change Using Remote Sensing and GIS in Rize, NorthEast Turkey. Sensor 2008, 8,6188-6202; 001:10.3390/s8106188. [Online]. Tersedia di www.mdpi.org/sensors. Diakses tanggal 27 Mei 2014.

Sonis,M.,M.Shoshany and N. Goldshlager. (2007). Landscape Changes in The Israel Carmel Area An Application of Matrix Land-Use Analysis. Modelling Land-Use Change, pp. 61-82.

Sutanto. (1999). Penginderaan Jauh. Cet.4. Yogyakarta: Gajah Mada University Press.

Wang, Si Yuan et al. (2010). Dynamics and changes in spatial patterns of land use in Yellow River Basin, China. Land Use Policy 27 (2010) 313-323. [Online]. Tersedia di Journal homepage: www.elsevier.com/locate/landusepol. Diakses tanggal 7 Juli 2011.

Yunus, Hadi Sabari. (2005). Klasifikasi Kota. Yogyakarta : Pustaka Pelajar Offset.

Zahnd, Markus. (1999). Perancangan Kota Secara Terpadu : Teori Perancangan Kota dan Penerapannya. Yogyakarta: Penerbit Kanisius bekerjasama dengan Soegijapranata University Press. 